\title{
Biomarkers in AL Amyloidosis
}

\author{
Despina Fotiou (D), Foteini Theodorakakou (D) and Efstathios Kastritis *(D)
}

check for

updates

Citation: Fotiou, D.; Theodorakakou, F.; Kastritis, E. Biomarkers in AL Amyloidosis. Int. J. Mol. Sci. 2021, 22, 10916. https://doi.org/10.3390/ ijms222010916

Academic Editor: Vladimir Tesar

Received: 14 September 2021

Accepted: 7 October 2021

Published: 9 October 2021

Publisher's Note: MDPI stays neutral with regard to jurisdictional claims in published maps and institutional affiliations.

Copyright: (c) 2021 by the authors. Licensee MDPI, Basel, Switzerland. This article is an open access article distributed under the terms and conditions of the Creative Commons Attribution (CC BY) license (https:// creativecommons.org/licenses/by/ $4.0 /)$.
Department of Clinical Therapeutics, School of Medicine, National and Kapodistrian University of Athens, 11528 Athens, Greece; desfotiou@gmail.com (D.F.); foteint@gmail.com (F.T.)

* Correspondence: ekastritis@gmail.com

\begin{abstract}
Systemic AL amyloidosis is a rare complex hematological disorder caused by clonal plasma cells which produce amyloidogenic immunoglobulins. Outcome and prognosis is the combinatory result of the extent and pattern of organ involvement secondary to amyloid fibril deposition and the biology and burden of the underlying plasma cell clone. Prognosis, as assessed by overall survival, and early outcomes is determined by degree of cardiac dysfunction and current staging systems are based on biomarkers that reflect the degree of cardiac damage. The risk of progression to end-stage renal disease requiring dialysis is assessed by renal staging systems. Longer-term survival and response to treatment is affected by markers of the underlying plasma cell clone; the genetic background of the clonal disease as evaluated by interphase fluorescence in situ hybridization in particular has predictive value and may guide treatment selection. Free light chain assessment forms the basis of hematological response criteria and minimal residual disease as assessed by sensitive methods is gradually being incorporated into clinical practice. However, sensitive biomarkers that could aid in the early diagnosis and that could reflect all aspects of organ damage and disease biology are needed and efforts to identify them are continuous.
\end{abstract}

Keywords: AL amyloidosis; biomarker; Mayo cardiac staging; NT-proBNP; plasma cell clone; serum free light chains; minimal residual disease; growth differentiation factor-15

\section{Introduction}

Immunoglobulin light chain (AL) amyloidosis is a rare and heterogenous hematological disorder characterized by the production and extracellular deposition of misfolded immunoglobulin free light chains (FLCs) that form amyloid fibrils and which originate from plasma cell or other B-cell clones [1]. FLC-derived amyloid fibrils deposit on target tissues causing disruption of their architecture and organ dysfunction [2]. Outcomes are currently poor and the non-specific and insidious nature of symptom presentation leads to delayed diagnosis and early mortality. Sensitive biomarkers for early diagnosis and biomarkers with prognostic value are necessary to guide appropriate treatment decisions and to serve as surrogate markers for clinical endpoints to allow new drug approvals by regulatory authorities.

Prognosis in AL amyloidosis and particularly early mortality are largely dependent on the pattern and degree of end-organ-damage by the amyloidogenic FLC. Cardiac involvement is the critical determinant of survival and efforts have largely focused on devising prognostic tools that assess the degree of cardiac dysfunction $[1,3,4]$. The current standard staging systems include biomarkers of cardiac dysfunction-cardiac troponins, brain natriuretic peptide (BNP) and its N-terminal pro-brain natriuretic peptide (NT-proBNP) [5-7]. Factors that relate to the underlying clonal disorder also have prognostic value particularly for longer-term outcomes and treatment response. A revised version includes FLCs as a marker of the burden of circulating free light chains [8]. Renal involvement is a major cause of morbidity due to risk for progression to end-stage renal disease requiring dialysis but the search for renal biomarkers has always come second given the dramatic effect of 
cardiac involvement in overall mortality. A renal staging system has also been proposed and is widely used $[9,10]$.

As early mortality remains a significant issue, prognostic factors in early survivors with outcomes based on landmark analysis are expected to differ from those used for "intention-to-treat analysis" at baseline. Current staging systems seem to fall short in their prognostic ability in the longer-term.

In this paper we will review the currently used biomarkers in AL amyloidosis and the unmet needs. Given disease complexity, biomarkers have gained importance over recent years, as accurate estimates of prognosis and subsequent disease monitoring are necessary. A biomarker that entails all aspects of the disease in a sensitive but also specific manner (cardiac damage, renal failure, monoclonal plasma cell burden, and toxic free light chain circulation) is missing [11]. A number of new biomarkers have been reported in recent years and although none has made it to everyday clinical practice or has been incorporated in clinical trial design, emerging new data is promising.

\section{Current Prognostic Staging Systems and Biomarkers}

Given the significant prognostic impact of cardiac involvement with early death it is only reasonable that markers of cardiac injury and dysfunction have emerged over the years as powerful prognostic factors.

Serum levels of NT-proBNP and cardiac troponin T (cTnT) were first found to predict survival in several cohorts of AL patients $[5,7,12,13]$. They were later incorporated into the first widely used staging system for AL amyloidosis (Mayo 2004) which defines three stages [6]. The composition and biomarker thresholds were subsequently revised and two modifications of the original score are widely accepted $[7,8]$ (Table 1). The original Mayo score includes NT-proBNP and troponin T and the 2012 revision incorporates the difference between the involved and the uninvolved FLC. The European version of the 2004 Mayo system identifies patients with very high NT-proBNP levels as having very poor outcomes and splits stage III into two stages (IIIla and IIIlb) based on the $8500 \mathrm{ng} / \mathrm{L}$ cutoff for NT-proBNP.

Table 1. Mayo staging systems and renal staging systems. NT-proBNP, amino-terminal portion of pro-brain natriuretic peptide type B; BNP, natriuretic peptide type B; cTnT, cardiac troponin T; cTnI, cardiac troponin I; hs-cTnT, high-sensitivity cardiac troponin; dFLC, difference between involved and uninvolved free light chain concentration; eGFR, estimated glomerular filtration rate.

\begin{tabular}{|c|c|c|c|c|}
\hline & Markers and Cutoffs & Stages & Median OS, Months & HR for OS \\
\hline \multicolumn{5}{|l|}{ Cardiac } \\
\hline \multirow[t]{3}{*}{ Mayo 2004 [6] } & \multirow{3}{*}{$\begin{array}{l}\text { NT-proBNP }>332 \mathrm{ng} / \mathrm{L} \\
\mathrm{BNP}>81 \mathrm{ng} / \mathrm{L} \\
\mathrm{cTnT}>0.035 \mathrm{ng} / \mathrm{mL}(\mathrm{cTnI}> \\
0.01 \mathrm{ng} / \mathrm{mL})\end{array}$} & I: no marker above the cutoff & 130 & Reference \\
\hline & & II: one marker above the cutoff & 54 & 2.3 \\
\hline & & III: both markers above the cutoff & 10 & 6.4 \\
\hline \multirow[t]{4}{*}{$\begin{array}{l}\text { European } \\
\text { modification [7] }\end{array}$} & \multirow{4}{*}{$\begin{array}{l}\text { Like Mayo } 2004 \text { Mayo } \\
\text { III is divided into two groups } \\
\text { NT-proBNP > } 8500 \mathrm{ng} / \mathrm{L} \text { (or } \\
\text { BNP } 700 \mathrm{ng} / \mathrm{L} \text { ) }\end{array}$} & I & 130 & Reference \\
\hline & & II & 54 & 2.4 \\
\hline & & $\begin{array}{l}\text { IIIa: both markers above the cutoff } \\
\text { and NT-proBNP }<8500 \mathrm{ng} / \mathrm{L}\end{array}$ & 24 & 4.2 \\
\hline & & $\begin{array}{l}\text { IIIb: Mayo stage III and } \\
\text { NT-proBNP }>8500 \mathrm{ng} / \mathrm{L}\end{array}$ & 4 & 11.3 \\
\hline \multicolumn{5}{|c|}{ Cardiac + Tumor-related } \\
\hline \multirow[t]{4}{*}{ Mayo 2012 [8] } & NT-proBNP > 1800 ng/L & I: no marker above cutoff & 130 & Reference \\
\hline & $\mathrm{cTnT}>0.25 \mathrm{ng} / \mathrm{mL}$ & II: 1 marker above cutoff & 72 & 1.8 \\
\hline & $\mathrm{dFLC}>180 \mathrm{mg} / \mathrm{L}$ & III: 2 markers above cutoff & 24 & 3.7 \\
\hline & & IV: 3 markers above cutoff & 6 & 7.1 \\
\hline
\end{tabular}


Table 1. Cont.

\begin{tabular}{lccc}
\hline & Markers and Cutoffs & Stages & Median OS, Months \\
\hline Renal & & HR for OS \\
\hline Palladini et al. 2014 [9] & eGFR $<50 \mathrm{~mL} / \mathrm{min} / 1.73 \mathrm{~m}^{2}$ & $\begin{array}{c}\text { I: both eGFR and proteinuria } \\
\text { below cutoff }\end{array}$ & 0\% risk of dialysis at 3 years \\
\hline & proteinuria $>5 \mathrm{~g} / 24 \mathrm{~h}$ & $\begin{array}{c}\text { II: either eGFR below or } \\
\text { proteinuria above the cutoffs }\end{array}$ & $7 \%$ risk of dialysis at 2 years \\
\hline & $\begin{array}{c}\text { III: both eGFR below and } \\
\text { proteinuria above the cutoff }\end{array}$ & $60 \%$ risk of dialysis at 2 years \\
\hline
\end{tabular}

Cardiac troponins $\mathrm{T}(\mathrm{cTnT})$ and $\mathrm{I}(\mathrm{cTnI})$ are very sensitive and specific markers of cardiac injury. Sensitivity is increased with the use of next-generation high-sensitivity assays [13]. Subtle myocyte damage leads to release of troponin and abnormal serum levels due to high concentrations within the myocardium, a high release ratio, and prolonged elevation after injury [14-16].

Deposition of amyloid fibrils and direct toxicity of the clonal free light chains in the myocardium leads to increased wall stress, mostly in the left ventricle, the activation of p38-MAPkinase pathway, and induction of proBNP in the cardiac myocytes. Once released, proBNP, which is a 108-amino acid propeptide, is cleaved into the active brain natriuretic peptide (BNP) and a leader sequence, NT-proBNP. NT-proBNP has emerged as a very sensitive marker of cardiac failure which is elevated in the asymptomatic stages of left ventricular dysfunction. NT-proBNP levels change quickly with treatment and therefore may also serve as a reliable indicator of treatment response [17]. The FLC test, allows for sensitive quantification of the involved FLC and underlying clonal disorder [18-20], and the addition of dFLC on cardiac biomarkers in the Mayo 2012 revision added more long-term prognostic information, since FLC levels reflect the underlying clonal disease burden [21,22].

The combination of troponin T and NT-proBNP provides an objective, reproducible risk assessment tool based on biochemical criteria. However, serum troponins and NTproBNP levels are influenced by renal dysfunction and other factors such as fluid overload and atrial arrythmias. Their reliability in these settings is therefore questioned [23,24] and regulatory authorities remain skeptical about their use as primary endpoints in clinical trials. Dittrich et al. [25] compared the performance of the staging systems in the context of atrial fibrillation and renal dysfunction (estimated glomerular filtration rate $(\mathrm{eGFR})<50 \mathrm{~mL} / \mathrm{min} / 1.73 \mathrm{~m}^{2}$ ). The least precise staging system in the entire cohort was Mayo2004 but European modification with addition of stage IIIlb was the most robust. Performance of all systems was almost unaffected by renal impairment but less so by atrial arrythmias.

While heart involvement and cardiac biomarkers have driven patients' survival and therapeutic options, renal biomarkers are used in order to predict renal survival and progression to dialysis.

The use of proteinuria and eGFR have been validated in thousands of patients with renal diseases and they have been used as endpoints in clinical trials. Current staging systems for prognosis of the renal disease and kidney response to treatment are based on serial eGFR and proteinuria assessments. However, neither marker is specific nor sensitive nor do they represent direct injury of kidney cells. Notably their levels are affected when kidney damage may already be advanced and irreversible, while heart failure can also contribute to impaired renal function (as measured by eGFR). In a small percentage of patients, where amyloid deposits affect renal vasculature rather than glomeruli, rapid deterioration of creatinine may be the dominant feature of renal involvement without proteinuria [26], so renal response criteria based on proteinuria cannot be reliable. Moreover, hematological response to therapy is assessed as early as in the first month after initiation of therapy. With the established criteria, renal response is time-dependent and a profound decrease 
in proteinuria may be observed after a period of 6 to 12 months following hematologic response.

However, proteinuria with $24 \mathrm{~h}$ urine collection and eGFR are easy to measure and widely available. Palladini et al. in 2014 developed and validated a renal staging system defined by the cutoffs of $5 \mathrm{gr} / 24 \mathrm{~h}$ for proteinuria and $50 \mathrm{~mL} / \mathrm{min} / 1.73 \mathrm{~m}^{2}$ for eGFR. According to their results, the probability of progression to dialysis within 3 years was $0 \%$ to $4 \%$ for renal stage I, $7 \%$ to $30 \%$ for renal stage II, and $60 \%$ to $85 \%$ for renal stage III [9]. They also defined renal response and progression criteriabaseline of $25 \%$ or more was associated with higher probability of end-stage renal disease (ESRD) and defined "renal progression", while a reduction in proteinuria of more than $30 \%$ from baseline or below $0.5 \mathrm{gr} / 24 \mathrm{~h}$, without fulfilling criteria for renal progression, was correlated with longer renal survival [9] and defined as "renal response". It was proposed that these criteria could be used in order to evaluate response to treatment along with hematologic response and cardiac response criteria as early as in 3 and 6 months after start of therapy.

Even though creatinine, eGFR, and proteinuria are established biomarkers, they can be influenced by many factors such as hydration status, diuretic use, fluctuations in weight, and comorbidities. According to Palladini criteria, progression of renal disease is only defined by eGFR (that is serum creatinine); however, the identification of patients with inadequate renal response has clinical relevance. Because of the limitations with the use of eGFR alone, the effort to develop more sensitive biomarkers continues. In another approach, Kastritis et al. introduced the $24 \mathrm{~h}$ proteinuria to eGFR ratio ( $24 \mathrm{hUPr} / \mathrm{eGFR})$ as a potentially more sensitive and accurate biomarker for evaluation of renal progression. The ratio incorporates both proteinuria and eGFR without additional testing. The analysis showed that an increase by at least $25 \%$ or a ratio $>100$ at 3 and 6 months after initiation of therapy correlated with higher risk of ESRD. In addition, patients with renal involvement could be stratified in three stages based on baseline $24 \mathrm{hUPr} / \mathrm{eGFR}$ ratio and these stages could also predict the risk of progression to dialysis in accordance to Palladini criteria. Thus, a ratio below 30 was associated with $0 \%$ risk of progression to dialysis at 3 years, a ratio between 30 and 99 was associated with $11 \%$ probability and a ratio over 100 with $46 \%$ probability of dialysis at 3 years [10]. This staging system could further separate patients at intermediate risk per the Palladini system, providing additional prognostic information. The two staging systems have been compared in an independent cohort, revealing their limitations [27].

\section{Other Markers of Organ-Related Dysfunction Associated with Prognosis}

Table 2 summarizes markers of organ dysfunction that have been evaluated to have adverse outcomes in patients with AL amyloidosis over the past years.

Table 2. Prognostic significance of organ-function related biomarkers in AL amyloidosis. NT-proBNP, amino-terminal portion of pro-brain natriuretic peptide type B; MVA, multivariate analysis; UVA, univariate analysis; OS, overall survival; EFS, event-free survival; RS, renal survival; BNP, natriuretic peptide type B; cTnT, cardiac troponin T; cTnI, cardiac troponin I; hs-cTnT, high-sensitivity cardiac troponin; LV, left ventricle; NYHA, New York Heart Association; echo, echocardiogram; ECF, electrocardiogram; MRI, cardiac magnetic resonance tomography; LVEF, left ventricular ejection fraction; GLS, global longitudinal strain; eGFR, estimated glomerular filtration rate.

\begin{tabular}{|c|c|c|c|c|}
\hline Biomarkers & & Thresholds & Prognostic Significance & Reference Number \\
\hline NT-proBNP & serum & $\begin{array}{c}>152 />332 />18,000 />2736 \mathrm{pg} / \mathrm{ML} \\
>8500 \mathrm{pg} / \mathrm{ml}\end{array}$ & $\begin{array}{l}\text { Adverse OS in MVA } \\
\text { Adverse OS in MVA }\end{array}$ & {$[6-8,28]$} \\
\hline $\mathrm{BNP}$ & Serum & $\begin{array}{l}>81 \mathrm{pg} / \mathrm{mL} \\
>700 \mathrm{pg} / \mathrm{mL}\end{array}$ & $\begin{array}{c}\text { Equivalent to NT-proBNP }>332 \\
\text { pg/mL } \\
\text { Equivalent to NT-proBNP }>8500 \\
\text { pg/mL }\end{array}$ & [29] \\
\hline $\mathrm{cTnT}$ & $\begin{array}{l}\text { Plasma } \\
\text { Serum }\end{array}$ & Continuous or $>0.03 / \geq 0.035 \mu \mathrm{g} / \mathrm{L}$ & Adverse OS in MVA & {$[5,6,8]$} \\
\hline
\end{tabular}


Table 2. Cont.

\begin{tabular}{|c|c|c|c|c|}
\hline Biomarkers & & Thresholds & Prognostic Significance & Reference Number \\
\hline cTnI & $\begin{array}{l}\text { Plasma } \\
\text { Serum }\end{array}$ & Continuous or $>70 />100 \mathrm{ng} / \mathrm{L}$ & Adverse OS in MVA & {$[5,6,28]$} \\
\hline hs-cTnT & Plasma serum & Continuous or $\geq 14 / 5054 />77 \mathrm{ng} / \mathrm{L}$ & Adverse OS in MVA & {$[28,30,31]$} \\
\hline Ejection fraction & Echo (LVEF) & EF continuous or $<45 \% / 50 \%$ & Adverse OS in MVA & {$[5,6,30]$} \\
\hline LV longitudinal function & Echo (GLS) & $\begin{array}{l}\text { GLS }<-11.8 \% \\
\text { GLS } 17 \%\end{array}$ & $\begin{array}{c}\text { Adverse OS in MVA } \\
\text { discriminated survivors from } \\
\text { non-survivors and added prognostic } \\
\text { value within each cardiac staging } \\
\text { system }\end{array}$ & {$[32,33]$} \\
\hline LV septum thickness & Echo & $>15 \mathrm{~mm}$ & Adverse OS in MVA & {$[5,6]$} \\
\hline NYHA class & & $>2$ & Adverse OS in MVA & [28] \\
\hline Atrial arrhythmia & ECG & Presence & Adverse OS in MVA & {$[25,34]$} \\
\hline Systolic blood pressure & & $<100 \mathrm{mmHg}$ & Adverse OS in MVA & [7] \\
\hline Uric acid & Serum & $>8 \mathrm{mg} / \mathrm{dL}$ & Adverse OS in MVA & [35] \\
\hline $\begin{array}{l}\text { Albumin-to creatinine } \\
\text { ratio }\end{array}$ & & $\begin{array}{c}3600 \mathrm{mg} / \mathrm{gr} \\
3600 \mathrm{mg} / \mathrm{gr} \\
220 \mathrm{mg} / \mathrm{mmol}\end{array}$ & $\begin{array}{c}\text { Adverse RS } \\
\text { Adverse RS } \\
\text { Adverse EFS }\end{array}$ & [36-38] \\
\hline Albumin & & cont or $\leq 30 \mathrm{~g} / \mathrm{L}$ & & {$[6,9]$} \\
\hline Proteinuria & & $>5 \mathrm{~g} / 24 \mathrm{~h}$ & & {$[6,9]$} \\
\hline EGFR & & $<50 \mathrm{~mL} / \mathrm{min}$ & $\begin{array}{l}\text { Adverse OS in MVA } \\
\text { Adverse RS in MVA }\end{array}$ & {$[9,25]$} \\
\hline
\end{tabular}

\subsection{Markers of Cardiac Dysfunction}

In addition to NT-proBNP and cardiac troponin, low arterial blood pressure $(<100 \mathrm{mmHg}$ ) [7], high New York Heart Association class (NYHA) $(>2)$ [28], and the presence of atrial arrythmias $[25,34]$ have been linked to worse prognosis in patients with AL amyloidosis. The presence of atrial arrythmia retained its prognostic adverse value in a multivariate model which also included age, $\mathrm{dFLC}$, and cardiac staging systems in a recent study by Dittrich et al. [25] In the study by Sidana et al. in 2019, Holter monitoring was used for arrhythmia evaluation and atrial fibrillation (HR, 2.5; 95\% CI, 1.2-5.0; $p=0.02$ ) and non-sustained ventricular tachycardia (SVT) (HR, 2.0; 95\% CI, 1.1-3.5; $p=0.02$ ) were independent predictors of overall survival (OS) after accounting for Mayo stage and age. However, these markers have not been incorporated in a formal risk stratification system although they are commonly used in every day clinical practice and may guide treatment and patient management.

Cardiac Imaging

Cardiac Echocardiography

Cardiac echocardiography is an important tool for the diagnosis of cardiac AL and evaluation of the degree of cardiac dysfunction. Left ventricular ejection fraction measurement by echocardiography (LVEF) is typically used to assess cardiac systolic function and many studies have reported an association between low LVEF and adverse prognosis. LVEF in cardiac AL is generally preserved until late disease stages and low LVEF is therefore an indicator of very advanced cardiac amyloidosis. Kristen et al. in 2010 identified LVEF $<45 \%$ as an independent prognostic factor for OS in multivariate analysis (MVA) that included NT-proBNP and hsTnT in a prospective study of 163 newly diagnosed patients. [30] A 
higher cutoff value of 55\% for LVEF was also reported to be an independent prognostic factor for OS in patients with newly diagnosed AL amyloidosis in two studies $[5,6]$.

LVEF provides an estimate of the geometric changes that occur to the LV secondary to cardiac dysfunction. The quantification of longitudinal cardiac fiber function is considered to be a better measure of contractile myocardial [39]. In AL amyloidosis the subendocardial myocardium is affected first (as determined by cardiac MRI) and longitudinal fibers are mostly located in the subendocardium. This explains the prognostic implication of global longitudinal function evaluation in patients with preserved LVEF [40]. In the study by Buss et al. in 2012, in 206 consecutive patients with biopsy proven cardiac AL, echocardiography was used to assess mean tissue doppler-derived longitudinal strain (LS), and two-dimensional global longitudinal strain (2D-LGS) of the LV [32]. Reduced LS and 2D-GLS were both independently associated with OS using the cut-offs of $-10.65 \%$ and $-11.78 \%$, respectively. There was a strong correlation of both parameters with NT-proBNP. In the clinical MVA model, 2D-GLS and cTnT were independent predictors of survival in AL amyloidosis and 2D-GLS provided incremental value to the combination of NT-proBNP, cTnT, and other clinical parameters. In the study by Pun et al. in 2018 [33], in 82 patients with newly diagnosed AL amyloidosis, the cutoff value of $17 \%$ for GLS (they converted negative to positive values) was reported as the value that best discriminated survivors from non-survivors at 5 years, with an HR that was 0.91 (95\% CI, 0.74-0.90, $p<0.001$ ) in univariate analysis (UVA), but MVA was not performed. GLS provided added value to risk stratification within each validated cardiac staging system. Other studies have also identified GLS as a prognostic marker for outcome in AL [41-43]. Increased LV septum thickness as reported by echocardiography has also been linked to adverse prognosis. In two MVA models reported by Dispenzieri et al. in 2003 [5] and 2004 [6] LV septal thickness $>15 \mathrm{~mm}$ retains its independent prognostic value, however, there are several limitations with its reproducibility.

\section{Cardiac Magnetic Resonance (MRI)}

MRI is currently a necessary part of the AL amyloidosis work-up at diagnosis; it contributes to the diagnostic process and can differentiate cardiac amyloidosis from other causes of cardiomyopathy. Global diffuse myocardial late gadolinium enhancement (LGE) is more pronounced in subendocardial layers in cardiac amyloidosis and it has been associated with poor prognosis [44]. Other cardiac MRI parameters are increasingly emerging as markers of prognosis as they reflect cardiac dysfunction. Arenja et al. demonstrated in 2019 the prognostic value of longitudinal axis strain (LAS) and myocardial contraction fraction (MCF) in 74 patients with biopsy-proven AL amyloidosis [45]. LAS is a marker of longitudinal function of the $\mathrm{LV}$ and is defined as the percentage of longitudinal shortening of the LV between end-diastole and end-systole. MCF is calculated by dividing LV stroke volume by LV myocardial volume. Both of these parameters are unaffected by other organ dysfunction and can be extracted without dedicated processing software and without the use of gadolinium contrast which is often contraindicated in patients with renal impairment. Patients with eGFR less than $30 \mathrm{~mL} / \mathrm{min} / 1.73 \mathrm{~m}^{2}$ and cardiac pacemakers or other metallic implants were excluded from the study. Primary endpoint was all-cause mortality and the secondary composite endpoint included cardiac transplantation due to progressive disease. Cutoff points were determined at $\leq 56.6 \%$ for MCF and at $<-7 \%$ for LAS. In UVA, LAS (HR $=1.05, p<0.00)$ and MCF $(\mathrm{HR}=0.96, p<0.001)$ were associated with reduced transplant-free survival. Kaplan-Meier analyses for both endpoints showed reduced event-free survival in patient with LAS $>-7 \%$ and MCF of $56.6 \%$. Adding LAS and MCF to LVEF increased the predictive power of the model. Correlations between CMR-derived parameters (MCF and LAS) and cardiac NT-proBNP and cTNT was weak to moderate.

Extracellular volume (ECV), as assessed by MRI, provides an assessment of amyloid burden in the heart, together with T1. Comparison studies have demonstrated that ECV and T1 can reliably distinguish between amyloidosis and other disease states [46]. In a 
study of $100 \mathrm{AL}$ amyloidosis patients with a median follow up of 2 years, ECV > 44\% (HR, $7.2 ; 95 \%$ CI, 1.751-13.179; $p=0.002$ ) was an independent prognostic factor for mortality and correlated with Mayo stage and LVEF [47].

\subsection{Markers of Renal Dysfunction}

A practical issue with the use of proteinuria in the assessment of renal impairment is that the collection of 24-h urine is inconvenient. Other alternatives have been proposed to measure the loss of protein. Other markers of renal function that have been linked to prognosis include albumin and the albumin to creatinine ratio. In univariate analysis serum albumin levels $<30 \mathrm{~g} / \mathrm{L}$ predicted renal survival, however, the prognostic effect was not significant in MVA [9]. The urinary albumin to creatinine ratio (uACR) has been proposed as an alternative method to stratify and evaluate renal response to therapy and has a good correlation to $24 \mathrm{~h}$ urine protein. At the time of diagnosis, values of more than $500 \mathrm{mg} / \mathrm{g}$ define renal involvement while values of more than $3600 \mathrm{mg} / \mathrm{g}$ are predictive for renal survival [36]. In the course of the disease, a reduction in uACR of more than $30 \%$ is an accurate biomarker to monitor renal response to treatment, even when eGFR is below $30 \mathrm{~mL} / \mathrm{min} / 1.73 \mathrm{~m}^{2}$, but an increase in uACR is not as reliable for assessing renal progression [37]. Biomarkers should also be evaluated in the framework of novel therapies. In patients receiving daratumumab-based regimens, uACR seems to have an adverse effect on the efficacy of therapy-based regimens probably due to loss of monoclonal antibodies in the urine [38].

\section{Tumor-Related Biomarkers}

Tumor-related biomarkers correspond to characteristics of the underlying clonal disorder, the burden and qualities of the clonal plasma or other B-cells, and the secreted amyloidogenic FLCs. They have emerged as biomarkers that mostly correlate with longerterm outcomes in contrast to organ-function-related markers which are more predictive of short-term outcomes. They also have significant value in response assessment, patient monitoring, and tailoring of treatment. Table 3 summarizes all tumor-related biomarkers reported to have an impact on OS to date in AL amyloidosis. 


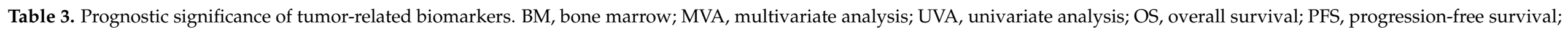

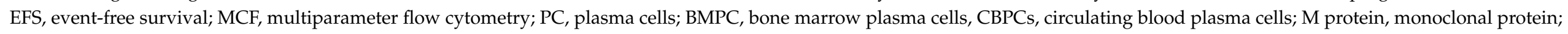

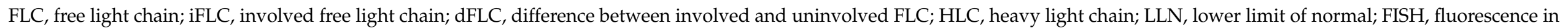
situ hybridization; HDM, high-dose melphalan in autologous stem cell transplant; M-dex, melphalan dexamethasone.

\begin{tabular}{|c|c|c|c|c|}
\hline Factor/Biomarker & & Thresholds or Adverse Factors & Prognostic Signfiicance & Reference \\
\hline \multirow[t]{6}{*}{ Bone marrow } & BM cytology or histology & $\geq 10 \%$ & MVA adverse OS and PFS & $\begin{array}{l}\text { Kourelis } 2013 \text { [48] } \\
\text { Tovar } 2018 \text { [49] }\end{array}$ \\
\hline & & $\geq 20 \%$ & MVA adverse OS & Muchtar 2019 [50] \\
\hline & BM-MCF & $>1 \%, \geq 2.5 \%$, MFC automated profile & MVA adverse OS and PFS & Puig 2019 [51] \\
\hline & BM MCF & $>1 \%$ clonal PC & MVA adverse OS and PFS & Paiva 2011 [52] \\
\hline & & $\geq 2.5 \%$ clonal PC & MVA adverse OS and PFS & Muchtar 2017 [53] \\
\hline & CBPCs & $>\overline{5} \times 10^{6} / \mathrm{L}$ or $>1 \%$ & Adverse OS (limited MVA) & Pardanani 2003 [54] \\
\hline M protein & Urine & Continuous or $>1 \mathrm{~g} / 24 \mathrm{~h}$ & MVA adverse OS & Dispenzieri 2003 [5] Dispenzieri 2004 [6] \\
\hline \multirow[t]{5}{*}{ FLC } & Serum iFLC & $>125 \mathrm{mg} / \mathrm{L}$ & MVA adverse OS & Palladini 2010 [28] \\
\hline & & $>152 \mathrm{mg} / \mathrm{L}$ and continuous & MVA adverse OS & Dispenzieri 2006 [55] \\
\hline & $\mathrm{dFLC}$ & $>50 \mathrm{mg} / \mathrm{L}$ & $\begin{array}{l}\text { MVA adverse OS, more frequent and severe heart } \\
\text { involvement }\end{array}$ & $\begin{array}{l}\text { Dittrich } 2017 \text { [18] } \\
\text { Milani } 2017 \text { [56] }\end{array}$ \\
\hline & & $>196 \mathrm{mg} / \mathrm{L}, \lambda>182 / \mathrm{k}>294 \mathrm{mg} / \mathrm{L}$ & $\begin{array}{l}\text { MVA for OS and more frequent and severe heart } \\
\text { involvement }\end{array}$ & Kumar 2010 [21] \\
\hline & & $>180 \mathrm{mg} / \mathrm{L}$ & MVA for OS & $\begin{array}{l}\text { Kumar et al. } 2012 \text { [8] } \\
\text { J Sachchithanantham } 2017 \text { [22] }\end{array}$ \\
\hline Immuno-paresis & HLC immunoassay & $\begin{array}{c}\text { Severe HLC immunosuppression ( } \geq 2 \text { Ig } \\
\text { isotypes } \\
\text { suppressed by }>50 \% \text { below normal levels) }\end{array}$ & $\begin{array}{l}\text { Cardiac involvment in landmark analysis at } 6 \text { months } \\
\text { MVA OS }\end{array}$ & Sachchithanantham 2017 [22] \\
\hline \multirow[t]{2}{*}{ Any chromosomal aberration } & FISH/BM & Presence & $\begin{array}{l}\text { Increased plasmacytosis, cardiac involvment, adverse } \\
\text { OS in MVA }\end{array}$ & Hammons 2018 [58] \\
\hline & & & Adverse OS in MVA, cardiac involvement & Warsame 2015 [59] \\
\hline \multirow[t]{4}{*}{$\mathrm{t}(11 ; 14)$} & FISH/BM & Presence & Adverse OS when BMPC $\leq 10 \%$ & Warsame $2015[59]$ \\
\hline & & & Favorable OS after HDM/daratumumab & Bochtler 2016 [60] Kimmich 2020 [61] \\
\hline & & & Adverse OS in MVA & Bochlter $2015[38]$ \\
\hline & & & Adverse OS in MVA for bortezomib based regimens & Muchtar 2017 [62] \\
\hline \multirow[t]{2}{*}{ Gain of 1q21 } & $\mathrm{FISH} / \mathrm{BM}$ & Presence & Adverse OS and EFS in MVA for M-dex & Bochtler 2014 [63] \\
\hline & & & Adverse OS and EFS in UVA for daratumumab & Kimmich 2020 [61] \\
\hline Deletion of $17 p$ & FISH/BM & $>50 \%$ cells & Trend towards short OS & Wong 2018 [64] \\
\hline \multirow[t]{2}{*}{ Trisomies } & FISH/BM & presence & Adverse OS in MVA & Muchtar 2017 [62] \\
\hline & & & Adverse OS when BMPC > $10 \%$ & Warsame 2015 [59] \\
\hline
\end{tabular}




\subsection{Serum FLC}

FLC detection and quantification provides a sensitive way to quantify the amyloid precursor protein secreted by the monoclonal plasma cell in AL amyloidosis patients who usually lack an intact pathological immunoglobulin and have small plasma cell clones compared to other plasma cell disorders [18]. It is currently considered essential for the diagnosis and monitoring of AL amyloidosis patients [2]. The introduction of a nephelometric antibody-based for the quantification of serum FLC (Freelite, Binding Site, UK) was revolutionary for the diagnosis and monitoring of patients with AL amyloidosis [20,65]. Approximately 10 years later, another assay based on monoclonal antibodies became commercially available [66]. As expected, FLC levels correlate to a degree with organ involvement and the degree of organ dysfunction as they reflect amyloidogenic protein and tumor burden. Many studies have validated the prognostic value of FLCs for OS either as the difference between the involved and uninvolved FLC (dFLC) or as the absolute value of the involved FLC (iFLC). Different dFLC and iFLC cutoffs have been reported to have prognostic value and the $180 \mathrm{mg} / \mathrm{L}$ threshold was incorporated in the revised Mayo staging system in $2012[8,21]$ (Table 1 ). In a retrospective analysis of 93 patients with AL amyloidosis baseline iFLC ( $>152 \mathrm{mg} / \mathrm{L})$ was associated with higher risk of death (HR, 2.6; $p<0.04)$, more involved organs, and higher troponin levels. iFLC was also prognostic of survival as a continuous variable (HR, 1.003; $p=0.013$ ) [55]. The cutoff value of $>125 \mathrm{mg} / \mathrm{L}$ retained its prognostic value for adverse OS in MVA by another group [28]. In a retrospective analysis of 783 patients $\mathrm{dFLC}$ of $<50 \mathrm{mg} / \mathrm{L}$ was reported as an independent prognostic factor for OS in MVA associated with better outcomes ( $\mathrm{HR}=0.50, p=0.003$ ). Patients with $\mathrm{dFLC}<50 \mathrm{mg} / \mathrm{L}$ also had lower levels of clonal plasma cells and less frequent cardiac involvement [18]. Milani et al. in 2017 [56] performed a similar study in parallel and validated the importance and the prognostic value of a low dFLC level $(<50 \mathrm{mg} / \mathrm{L})$ [56]. However, as the nephelometric FLC test cannot differentiate between clonal and polyclonal light chains in the setting of impaired renal function, the non-specific accumulation of serum FLC becomes a limiting factor in the setting of severe renal dysfunction [67].

\subsection{Bone Marrow Plasma Cell Burden:}

Serum FLC levels are dependent on the clonal plasma cell burden $[49,65]$ and a high number of bone marrow plasma cells (BMPC) usually translates to higher disease activity but the secretory activity of the plasma cells can be variable and sFLC levels are also dependent on the rate of elimination. Nevertheless, plasma cell burden, as assessed by bone marrow biopsy or cytology, has emerged as an adverse prognostic factor for outcome in AL amyloidosis $[48,49,68]$.

Kourelis et al. in 2013 [48] reported that a BMPC infiltration $>10 \%$ in patients with $\mathrm{AL}$ amyloidosis is a negative prognostic marker independent of age, Mayo stage, use of ASCT, or dFLC. A higher cutoff of $\geq 20 \%$ was reported by the same group in an update of the study [68] with median OS of 81,33 , and 12 months for $<5 \%, 5-19 \%$, and $\geq 20 \%$ BMPCs, respectively $(p<0.001)$. In MVA accounting for known prognostic factors, an independent prognostic role for $\geq 20 \%$ BMPCs but not for the other BMPC groups was demonstrated. Another group assessed circulating peripheral blood PCs (PBPCs) and reported a poorer median OS for patients with high PBPC \%s $(>1 \%)$ (median survival, 10 vs. 29 months, $p=0.002)$ and absolute PBPC counts $\left(>0.5 \times 10^{6}\right) / \mathrm{L}$ (median OS, 13 vs. 31 months, $p=0.003$ ). Both remained independent prognostic factors for OS in MVA [54].

\subsection{Immunophenotyping}

Multidimensional flow cytometry (MCF) has emerged as a method of high sensitivity for the detection of aberrant plasma cell clones in the BM and in the periphery. In the study by Muchtar et al. in 2017, monotypic PCs $\geq 2.5 \%$ at diagnosis, as detected by MFC was associated with shorter progression free survival (PFS) and OS compared to patients with $<2.5 \%$ (2-year PFS $41 \%$ vs. $56 \%, p=0.007 ; 2$-year OS $55 \%$ vs. $70 \%, p=0.01$ ) [69]. This cutoff 
remained an independent predictor of adverse outcomes for both PFS/OS in MVA. MFC is prognostic for AL at diagnosis and at the time of treatment. The lower cutoff of $>1 \%$ BMPC as evaluated by MFC was also reported by Paiva et al. in 2011 as an independent predictor for OS in MVA [52] ( $\leq 1 \%$ vs. $>1 \%$ BMPC cutoff; 2-year OS rates of $90 \%$ vs. $44 \%, p=0.02$ ).

More recently, Puig et al. [51] used an automated computerized algorithm which simultaneously assessed the degree of clonality and tumor burden and identified three patient subgroups-MGUS-like, intermediate, and MM-like. Patients with AL and a profile signature similar to MM patients had earlier mortality. The intermediate plus MM-like profiles had an independent adverse prognostic effect on PFS (HR 2.9, $p=0.01$ ) and OS (HR, 3.0; $p=0.03)$.

\subsection{Cytogenetics of the Plasma Cell Clone}

Fluorescence in situ hybridization (FISH) abnormalities have significant prognostic value in $\mathrm{MM}$ and in recent years it has become apparent that the same holds true for AL. The genetic landscape is however different. There is less hyperdiploidy [70] and a much higher prevalence of translocations in the immunoglobulin heavy chain locus; translocation $\mathrm{t}(11 ; 14)$ is commonly found in AL amyloidosis [63], linked to a less complex clonal landscape and the free light chain phenotype [63]. Determining the genetic profile of the plasma cell clone adds prognostic information to the assessment of the BMPC burden which is linked to more long-term outcomes and response to treatment.

High-risk cytogenetics seen in MM $(t(4 ; 14), t(14 ; 16)$, and del17) are not common in AL. More complex karyotype clones, however, and presence of del17 have an impact on outcome [64]. Gain of 1q21 is an independent adverse prognostic factor in AL patients and data from series where patients were treated with melphalan, dexamethasone, standard chemotherapy, and daratumumab [61,63]. Bochtler et al. reported an independent adverse prognostic role for $1 \mathrm{q} 21$ and OS in MVA (HR, 3.64; $p=0.003)$ along with established Mayo cardiac staging.

Translocation $\mathrm{t}(11 ; 14)$ is an adverse prognostic factor for patients treated with bortezomib [38,62] but this effect is overcome with daratumumab and ASCT $[60,61,71]$. In a group of 101 patients treated with bortezomib, the presence of $t(11 ; 14)$ remained an independent prognostic factor with NT-proBNP and dFLC in MVA for hematologic eventfree survival (HR, 2.94; 95\% CI 1.37-6.25; $p=0.006)$ and OS (HR, 3.13; 95\% CI, 1.16-8.33; $p=0.03)$ [38]. In another series of 692 patients, $\mathrm{t}(11 ; 14)$ was the most common abnormality seen in $49 \%$ of patients, followed by monosomy $13 q$ in $36 \% . t(11 ; 14)$ was associated with inferior OS in both the bortezomib (15 vs. 27 months, $p=0.05)$ and the immunomodulatory agent (IMiD)-treated groups (12 vs. 32 months, $p=0.05)$. Trisomies were also associated with poorer median OS and this effect remained significant in MVA for the entire cohort whereas the independent prognostic value of $t(11 ; 14)$ remained significant in MVA only in the bortezomib arm. In patients treated with HDM and ASCT the effect of $t(11 ; 14)$ was reversed and in a study by the same group, $t(11 ; 14)$ was seen in $59 \%$ of patients and had a favorable effect on outcome together with low dFLC in MVA [60]. Similarly in a cohort treated with daratumumab $\mathrm{t}(11 ; 14)$ was associated with better hematological EFS, whereas gain 1q21 and hyperdiploidy were adverse factors for OS and hematological EFS [61].

\subsection{Immunoparesis}

The role of immunoparesis as an adverse prognostic factor has also been demonstrated. In a cohort of 170 patients, using heavy light chain immunoassay (HLC) immunoparesis of at least one immunoglobulin $(\mathrm{Ig})$ isotype was identified in $85 \%$ of patients and severe immunoparesis ( $\geq 2$ Ig isotypes suppressed by $>50 \%$ below normal levels) in $18 \%$ of patients. In patients with cardiac involvement at the 6-, 9-, and 12-month landmark analysis severe HLC suppression was associated with shorter OS (median OS 8.8 vs. 29.9 months, $p=0.007$ ). A survival model which included severe HLC suppression and dFLC > $180 \mathrm{mg} / \mathrm{L}$ stratified patients into three different survival categories. The effect of immunosuppression was greatest at 6 months, at the time of chemotherapy comple- 
tion. In patients with renal involvement the impact of immunoparesis requires careful assessment as nephrotic syndrome leads to IgG loss into the urine [22]. In another group of 998 patients, immunosuppression was assessed by nephelometry and defined it as either the number of suppressed uninvolved Igs below the lower limit of normal and also by assessing the average relative difference (ARD) of the uninvolved Igs from the LLN. In MVA immunosuppression as assessed by both methods retained its negative prognostic impact [57].

\section{Prognosis and Response to Treatment}

Many of the markers with upfront prognostic value have also formed the basis of current hematologic and organ response criteria demonstrating their prognostic value in landmark analysis [72,73].

The important prognostic role of FLC levels in AL amyloidosis was confirmed by the fact that FLC assessment forms the basis of the hematologic response criteria [72]. The aim of plasma-cell directed therapy is to achieve rapid decrease and normalization of the sFLC and the quality of the FLC response is directly associated with survival and organ response $[73,74]$. A substantial improvement in outcomes is associated with at least a very good partial remission (a dFLC below $40 \mathrm{mg} / \mathrm{L}$ [72]. Normalization of the FLC ratio and their levels are required to establish a complete response (aCR) in addition to absence of the involved monoclonal protein component by serum and urine and negative immunofixation. [75] Given that some patients with AL amyloidosis have low baseline dFLC levels between 20 and $50 \mathrm{mg} / \mathrm{L}$, a threshold of $10 \mathrm{mg} / \mathrm{L}$ was established as an additional hematologic response parameter (low dFLC PR) for such patients. Later this was proposed for all patients with baseline dFLC > $20 \mathrm{mg} / \mathrm{L}[18,76,77]$. A prospective observational study has shown that this milestone translates into a benefit additional to VGPR and CR and longer time to treatment [78]. An aCR is the optimal endpoint and patients who fail to achieve it have shorter PFS. However, even a very small residual aberrant plasma cell clone can affect outcome by secreting even small amounts of toxic amyloidogenic light chains. Minimal residual disease (MRD) as assessed by next-generation flow cytometry has been used as a biomarker that can identify patients at high probability of organ response and very low probability of hematologic relapse [79,80].

\section{Novel biomarkers}

\subsection{New Prognostic Biomarkers for Survival}

A number of novel biomarkers have emerged in recent years in the attempt to improve risk stratification and outcome prediction in the AL amyloidosis population (Table 4).

Table 4. Prognostic significance of novel biomarkers in AL amyloidosis. GDF-15, growth differentiation factor-15; suPAR, soluble urokinase-type plasminogen receptor; Gal-3, galectin-3; vWF, von Willebrand factor; RDW, red cell distribution width; sST2, soluble suppression of tumorigenicity 2; LV, left ventricle; ECV, extracellular volume; FMD, flow-mediated dilatation; MRI, magnetic resonance tomography; MCF, myocardial contraction fraction of the LV; LAS, longitudinal axis strain; RS, renal survival; MVA, multivariate analysis; OS, overall survival; UVA, univariate analysis.

\begin{tabular}{|c|c|c|c|c|}
\hline Biomarkers & & Thresholds & Prognostic Significance & Reference Number \\
\hline GDF-15 & Serum & $\begin{array}{l}4000 \mathrm{pg} / \mathrm{mL} \\
7575 \mathrm{pg} / \mathrm{mL} \\
2300 \mathrm{pg} / \mathrm{mL}\end{array}$ & $\begin{array}{c}\text { Adverse RS MVA } \\
\text { and } \\
\text { Adverse OS MVA } \\
\text { Adverse OS } \\
\text { MVA }\end{array}$ & $\begin{array}{l}{[81]} \\
{[81]} \\
{[82]}\end{array}$ \\
\hline SUPAR & Serum & 7.2 at 6 months & Adverse RS & [83] \\
\hline Gal-3 & Serum & $\begin{array}{c}11 \mathrm{ng} / \mathrm{mL} \\
20.24 \mathrm{ng} / \mathrm{mL}\end{array}$ & $\begin{array}{c}\text { Adverse OS in UVA } \\
\text { Adverse OS MVA }\end{array}$ & $\begin{array}{l}84] \\
{[85]}\end{array}$ \\
\hline Osteopontin & Serum & $>426 \mathrm{ng} / \mathrm{mL}$ & $\begin{array}{c}\text { Adverse OS in MVA } \\
\text { no significant predictive value }\end{array}$ & $\begin{array}{l}{[86]} \\
{[82]}\end{array}$ \\
\hline
\end{tabular}


Table 4. Cont.

\begin{tabular}{|c|c|c|c|c|}
\hline Biomarkers & & Thresholds & Prognostic Significance & Reference Number \\
\hline vWF & Serum & $\geq 230.0 \mathrm{U} / \mathrm{dL}$ & Adverse OS MVA & [87] \\
\hline D-dimer & Serum & $\begin{array}{l}\text { D-dimer } \geq 1 \mu \mathrm{g} / \mathrm{mL} \\
\text { vs. }<0.5 \mu \mathrm{g} / \mathrm{mL} \text { and vs. } \\
<1.0 \text { but }>0.5 \mu \mathrm{g} / \mathrm{mL}\end{array}$ & Increased risk of mortality in MVA & {$[88]$} \\
\hline RDW & Serum & $\mathrm{RDW} \geq 13.8$ & $\begin{array}{c}\text { Adverse OS MVA } \\
\text { Also in subgroup with no cardiac } \\
\text { involvement }\end{array}$ & [89] \\
\hline sST2 & Serum & $\begin{array}{l}>32.6 \mathrm{ng} / \mathrm{mL} \\
\geq 30 \mathrm{ng} / \mathrm{mL}\end{array}$ & $\begin{array}{c}\text { Adverse OS in MVA and 1-year } \\
\text { survival } \\
\text { Adverse OS in MVA }\end{array}$ & $\begin{array}{l}{[82]} \\
{[84]}\end{array}$ \\
\hline $\begin{array}{l}\text { Myocardial contraction } \\
\text { fraction }\end{array}$ & MRI & $\mathrm{MCF} \leq 56.6 \%$ & Adverse OS in MVA & {$[45]$} \\
\hline $\begin{array}{l}\text { LV longitudinal axis } \\
\text { strain }\end{array}$ & MRI & LAS $<-7 \%$ & Adverse OS in MVA & [45] \\
\hline $\mathrm{ECV}$ & MRI & $>0.45$ & Higher mortality & [47] \\
\hline FMD & Doppler & $\geq 4.5 \%$ & Adverse OS in MVA & [90] \\
\hline
\end{tabular}

\subsubsection{D-dimers}

D-dimer levels reflect fibrin degradation and are commonly elevated in hematological malignancies. In a recent analysis of 897 patients with AL amyloidosis, $47 \%$ were found to have elevated D-dimer $(>0.5 \mu \mathrm{g} / \mathrm{mL})$. A normal D-dimer level of $\leq 0.5 \mu \mathrm{g} / \mathrm{mL}$ and a level of $>0.5 \mu \mathrm{g} / \mathrm{mL}$ but $<1.0 \mu \mathrm{g} / \mathrm{mL}$ was associated with a lower mortality risk (HR, 0.49 and 0.59 ) compared to D-dimer levels $\geq 1 \mu \mathrm{g} / \mathrm{mL}$ in multivariate analysis. This effect was independent of cardiac stage. The median overall survival was 5.86, 4.04, and 2.08 years for D-dimer levels of $\leq 0.5,>0.5$ but $<1$, and $\geq 1 \mu \mathrm{g} / \mathrm{mL}$, respectively $(p<0.001)$ [88]. The cause of this finding is currently unknown. It is hypothesized that it could indicate the presence of venous thromboembolism (71 patients had a clinically significant VTE) or arterial thrombi. The fibrinolytic pathway is known to be active in AL amyloidosis and could explain the increased D-dimer levels or it could be linked to underlying dysfunction and pathology in the endothelium and vasculature. The authors argue that D-dimer elevation may reflect the extent of systemic involvement in these patients.

\subsubsection{Von Willebrand Factor (vWF)}

In addition to the toxic effects of the circulating free light chains to the myocardium, it is hypothesized that there might be direct deposition and toxicity of the light chains to the endothelial cells (ECs) leading to altered vascular function. Von Willebrand factor (vWF) is a large multimeric glycoprotein produced, stored, and secreted mostly by the EC. vWF secretion by the EC is hypothesized to reflect EC stimulation or activation. The prognostic importance of VWF as a surrogate marker of endothelial dysfunction was assessed in 111 patients with newly diagnosed AL amyloidosis. VWF:Ag levels were significantly higher in patients with AL compared to that measured in healthy controls [87] and serum VWF:Ag $\geq 230 \mathrm{U} / \mathrm{dL}$ was associated with higher probability of early death and remained an independent predictor of death within 6 months even among patients with Mayo stage III, (1-year OS of $17 \%$ vs. $68 \%$ for patients with stage III disease and lower VWF levels, $p<$ 0.001). Among patients with stage IIIb disease, high VWF levels could further discriminate them into two outcome groups ( 2 vs. 6 months, $p=0.006)$.

\subsubsection{Red Cell Distribution Width (RDW)}

A high RDW is associated with ineffective erythropoiesis, renal dysfunction, cardiovascular disease, age-related clonal hematopoiesis, and overall mortality [91,92]. In one 
retrospective analysis in 94 newly diagnosed patients with AL amyloidosis a high RDW was associated with adverse prognosis (a cut-off of 13.8 was determined using ROC analysis). OS was significantly shorter for patients with high RDW $(p<0.001)$, which retained its adverse prognostic power on multivariate analysis, even for Mayo stage I or patients with normal NT-proBNP [89].

\subsubsection{Soluble Suppression of Tumorigenicity 2 (sST2)}

SST2 is an IL-1 receptor acting through IL-33 signalling. It is elevated in heart failure, acting as a decoy receptor of IL-33 to alleviate the cardioprotective effects of IL-33 [93]. It is hypothesized to be a marker of cardiac remodeling and myocardial fibrosis and it is predictive of mortality in patients with cardiac disease [94,95] in a manner independent of NT-proBNP and troponins [96,97]. sST2 could provide further prognostic insights for patients with AL and high troponin and NT-proBNP levels as it may indicate those who have the ability to heal/survive. It could also have implications for candidate selection for cardiac transplantation. Dispenzieri et al. [84] assessed sST2 levels and galectin-3 levels in 502 patients with AL amyloidosis. UVA patients with sST2 $<30 \mathrm{ng} / \mathrm{mL}$ vs. $\geq 30 \mathrm{ng} / \mathrm{mL}$ had significant differences in 1-year OS (81\% vs. $43 \%)$ and 5-year OS (52\% vs. $22 \%$ ) $(p<0.0001)$. sST2 remained independent of troponin, NT-proBNP, sFLC, and blood pressure in MVA. A new scoring system incorporating ST2 was generated and a 5-level scoring system was created with a risk ratio per level of 1.8 (95\% CI, 1.6-1.9). Kim et al. [82] also assessed sST2 in 73 newly diagnosed patients with AL amyloidosis and determined the optimal cut-off at $32.6 \mathrm{ng} / \mathrm{mL}$ for OS and 1 year mortality. sST2 had incremental prognostic value for OS in addition to NT-proBNP and TnT. A prognostic model including sST2 performed well even in advanced Mayo cardiac stages.

\subsubsection{Osteopontin}

Osteopontin (OPN) is a phosphoglycoprotein expressed and secreted by cardiomyocytes [98] among other cells and is involved in cardiac adaptation to biomechanical strain and myocardial injury. It has been linked to outcome in patients with cardiac failure and is emerging as a marker of cardiac disease severity [99,100]. In 150 patients with newly diagnosed AL amyloidosis [86], OPN levels were higher in patients with cardiac involvement and more advanced cardiac stage. The optimal cut-off was reported at $426.8 \mathrm{ng} / \mathrm{mL}$ which had independent prognostic value for all-cause mortality in MVA but it did not allow further discrimination of outcome among patients with low TnT or NT-proBNP.

\subsubsection{Flow-Mediated Dilatation (FMD)}

Low blood pressure in AL is most likely an indication of vascular impairment and is associated with worse outcomes. Low cardiac output, low oncotic pressure, and autonomic dysfunction have all been implicated as contributors. Another hypothesis is that low blood pressure is a compensatory mechanism. Markers of vascular reactivity could therefore add prognostic information and improve risk stratification [101]. Flow-mediated dilatation (FMD) of the brachial artery is a non-invasive marker of vascular reactivity which is augmented in conditions of hypotension and autonomic dysfunction [102,103]. Vascular reactivity in AL is relatively increased compared to controls and it is hypothesized it could correlate with autonomic dysfunction. FMD of the brachial artery was assessed in 115 newly diagnosed patients with AL amyloidosis [90]. FMD $\geq 4.5 \%$ (as determined by ROC analysis) was associated with early mortality and worse survival (hazard ratio, 2.11; 95\% CI, 1.17-3.82; $p=0.013$ ) even after adjustment for Mayo stage, nerve involvement and low systolic blood pressure and median OS of AL patients with FMD $\geq 4.5 \%$ was 21.3 months versus 71 months for patients with FMD $<4.5 \%$. In MVA (model including Mayo stage and nerve involvement or for NT-proBNP, high-sensitivity troponin T or both) it remained an independent predictor of mortality at 6 months. FMD $\geq 4.5 \%$ correctly reclassified both high-risk AL patients who experienced the event and lower risk subjects 
who survived until the end of the follow-up over the best prognostic model (early versus late mortality).

\subsection{New Prognostic Biomarkers for Renal Outcome}

\subsubsection{Growth Differentiation Factor-15 (GDF-15)}

GDF-15 is a member of the transforming growth factor- $\beta$ (TGF- $\beta$ ) cytokine superfamily produced by cardiomyocytes, macrophages, endothelial cells, vascular smooth muscle cells, and adipocytes in response to oxidative stress, inflammation, and ischemia [104]. Kastritis et al. reported that in AL amyloidosis patients' serum GDF-15 have prognostic value for renal outcome. GDF-15 level of more than $4000 \mathrm{pg} / \mathrm{mL}$ at baseline was strong predictor for progression to dialysis (HR, 4; 95\% CI, 1.16-13; $p=0.045)$ independently of the traditional renal stage. Changes in GDF-15 at 3 and 6 months post initiation of treatment were stronger predictors for renal survival than the established renal response and progression criteria ( $p=0$ 0.01) [81]. Importantly, a high GDF-15 level also correlated with poor OS independently of Mayo stage (HR, 1.9; 95\% CI, 1.1-3.9; $p=0.045)$, while reduction of more than $25 \%$ from baseline significantly improved patients' survival (2-year OS of $91 \%$ vs. $66 \%, p=0.03$ ) [81]. The results of this study were validated in an independent population.

However, GDF-15 is involved in heart failure too [105]. There was a strong correlation of GDF-15 with NT-proBNP $\left(\mathrm{R}^{2}=0.211\right.$ and 0.124 in the two cohorts; $p<0.001$ for both), hsTnT $\left(R^{2}=0.451\right.$ and $\left.p<0.001\right)$ and Mayo stage $(p=0.001)$. There was also significant correlation of the changes in GDF-15 and NT-proBNP in the course of the disease. Another independent group has investigated the role of GDF-15 as surrogate or additive prognostic biomarker in AL amyloidosis patients. Kim et al. showed that elevated GDF-15 was associated with poor survival (sensitivity $71 \%$, specificity $44 \%, p=0.004$ for 1-year mortality; sensitivity $80 \%$, specificity $58 \%, p=0.009$ for overall mortality), mean wall thickness, and reduced longitudinal function of left ventricle [82]. In multivariate analysis GDF-15 was independently associated with overall mortality (HR, 2.53; 95\% CI, 1.08-5.92; $p=0.032)$ [82].

GFD-15 is currently emerging as a marker with potential "unifying" function with prognostic value for survival, risk for dialysis, and treatment response [11]. It is elevated in $>90 \%$ of all patients at diagnosis and it is a marker of poor overall outcome independent of other cardiac biomarkers (more than two thirds of patients with GDF-15 $>7575 \mathrm{pg} / \mathrm{mL}$ die within one year of diagnosis). GDF-15 levels $>4000 \mathrm{pg} / \mathrm{mL}$ are the currently the only marker of progression to dialysis independent of other biomarkers and it also performs better than the current renal staging system. GDF-15 levels are also sensitive markers of response to treatment and levels drop fast with response (greater declines compared to NT-proBNP at 3 months). Despite its seemingly promising value and role, GDF-15 needs to demonstrate reproducibility in larger series. More needs to be understood with regard to the underlying pathophysiology as currently it is unclear what the reasons are for its renal prognostic significance.

\subsubsection{Soluble Urokinase-Type Plasminogen Receptor (suPAR)}

suPAR is the circulating form of a glycosyl-phosphatidylinositol-anchored membrane protein expressed on immunologically active cells, endothelial cells, and renal podocytes [106]. Elevated levels reflect activation of the immune system and have been associated with poor survival in various conditions such as cardiac failure and cancer $[107,108]$. Regarding kidney function, high suPAR levels are independently associated with chronic kidney disease (CKD) [109] and acute kidney injury (AKI) [110]. Kastritis et al. evaluated the role of suPAR as a potential novel biomarker for renal outcome. According to their results, median baseline suPAR levels were two- or three-fold higher compared to nonamyloidosis patients or the general population (6.6 vs. 3.04-3.7 vs. 2.1) [83]. In a similar way to focal segmental glomerulosclerosis, suPAR might participate in the pathogenesis of renal disease in AL amyloidosis. Higher suPAR levels at diagnosis were associated with eGFR decline $(p=0.008)$ and with renal progression as defined by Palladini criteria 
$(p=0.02)$. suPAR was also measured at 6 months and values over $7.2 \mathrm{ng} / \mathrm{mL}$ were strong predictors of progression to dialysis ( $2 \%$ vs. $20 \%$ at 2 years and $2 \%$ vs. $38 \%$ at 4 years, $p<0.001$ ), independent of renal stage, renal progression, or hematologic response [83]. There was no validation cohort and their results need further investigation.

\subsubsection{Galectin-3 (Gal-3)}

Gal-3 is a beta-galactoside-binding lectin, involved in fibrosis and inflammation and therefore plays an essential role in the development of heart failure and kidney injury. Elevated concentrations have been associated with progressive renal impairment and with all-cause mortality in patients with non-amyloidosis renal diseases [111]. A study conducted in 2015 including AL patients, could not prove that Gal-3 had predictive value in multivariate analysis [84]. In another study by Li et al. [112], baseline serum Gal-3 levels $>20.24 \mathrm{ng} / \mathrm{mL}$ were an independent predictor of all-cause mortality, in univariate (HR, $1.92 ; p<0.001)$ and multivariate analysis $(\mathrm{HR}, 2.65 ; p=0.033)$. Patients were stratified into four groups based on Gal-3, hs-cTnT, and dFLC levels. Median OS was 100, 60, 29, and 15 months, respectively $(p<0.01)$ [85]. More research including patients without renal involvement is required in order to validate the prognostic value of Gal-3 and whether this stratification system can be applied to the management of systemic AL amyloidosis.

\section{Conclusions}

Outcome in patients with AL amyloidosis is dependent on the synergistic effects of the baseline pattern and severity of organ involvement, the underlying clonal disease burden and biology, and the effectiveness of response to treatment. Given the detrimental impact of cardiac involvement on outcome, overall survival is mostly determined by cardiac involvement. Biomarkers of organ function are associated more with early survival and mortality. European modification of Mayo cardiac staging performs best. Cardiac staging is used in the clinical trial design setting to risk-stratify patients and tailor treatment. Renal biomarkers predict risk of progression to dialysis and renal staging systems have not yet currently been incorporated into clinical practice. Factors that reflect and characterize the underlying tumor disease burden and biology determine longer-term outcomes and responses to treatment. sFLC level and minimal residual disease assessment (by NGF) form the current and future basis of hematologic response criteria. Staging systems are continuously evolving and changing as are response criteria. Novel biomarkers have emerged in recent years and their value remains to be validated. A biomarker with a "unifying" role in terms of prognostic value for survival, risk of dialysis, and treatment response has not yet been identified. It is, however, unlikely that a single biomarker will be able to reflect the complexity and heterogeneity of the disease. It should, of course, be noted that current outcomes are determined by diagnostic tools and available therapeutic options which therefore indirectly affect the performance of staging systems and individual biomarkers. As new treatments emerge, current risk-stratification tools are expected to change and adapt in terms of applicability and value.

Funding: This research received no external funding.

Institutional Review Board Statement: Not applicable.

Informed Consent Statement: Not applicable.

Data Availability Statement: Not applicable.

Conflicts of Interest: The authors declare no conflict of interest. 


\section{References}

1. Kyle, R.A.; Greipp, P.R.; O'Fallon, W.M. Primary systemic amyloidosis: Multivariate analysis for prognostic factors in 168 cases. Blood 1986, 68, 220-224. [CrossRef]

2. Gertz, M.A.; Comenzo, R.; Falk, R.H.; Fermand, J.P.; Hazenberg, B.P.; Hawkins, P.N.; Merlini, G.; Moreau, P.; Ronco, P.; Sanchorawala, V.; et al. Definition of organ involvement and treatment response in immunoglobulin light chain amyloidosis (AL): A consensus opinion from the 10th International Symposium on Amyloid and Amyloidosis, Tours, France, 18-22 April 2004. Am. J. Hematol. 2005, 79, 319-328. [CrossRef] [PubMed]

3. Gertz, M.A.; Kyle, R.A. Amyloidosis: Prognosis and treatment. Semin. Arthritis Rheum. 1994, 24, 124-138. [CrossRef]

4. Kyle, R.A.; Gertz, M.A. Cardiac amyloidosis. Int. J. Cardiol. 1990, 28, 139-141. [CrossRef]

5. Dispenzieri, A.; Kyle, R.A.; Gertz, M.A.; Therneau, T.M.; Miller, W.L.; Chandrasekaran, K.; McConnell, J.P.; Burritt, M.F.; Jaffe, A.S. Survival in patients with primary systemic amyloidosis and raised serum cardiac troponins. Lancet 2003, 361, 1787-1789. [CrossRef]

6. Dispenzieri, A.; Gertz, M.A.; Kyle, R.A.; Lacy, M.Q.; Burritt, M.F.; Therneau, T.M.; Greipp, P.R.; Witzig, T.E.; Lust, J.A.; Rajkumar, S.V.; et al. Serum cardiac troponins and N-terminal pro-brain natriuretic peptide: A staging system for primary systemic amyloidosis. J. Clin. Oncol. 2004, 22, 3751-3757. [CrossRef]

7. Palladini, G.; Campana, C.; Klersy, C.; Balduini, A.; Vadacca, G.; Perfetti, V.; Perlini, S.; Obici, L.; Ascari, E.; d’Eril, G.M.; et al. Serum N-terminal pro-brain natriuretic peptide is a sensitive marker of myocardial dysfunction in AL amyloidosis. Circulation 2003, 107, 2440-2445. [CrossRef]

8. Kumar, S.; Dispenzieri, A.; Lacy, M.Q.; Hayman, S.R.; Buadi, F.K.; Colby, C.; Laumann, K.; Zeldenrust, S.R.; Leung, N.; Dingli, D.; et al. Revised prognostic staging system for light chain amyloidosis incorporating cardiac biomarkers and serum free light chain measurements. J. Clin. Oncol. 2012, 30, 989-995. [CrossRef]

9. Palladini, G.; Hegenbart, U.; Milani, P.; Kimmich, C.; Foli, A.; Ho, A.D.; Vidus Rosin, M.; Albertini, R.; Moratti, R.; Merlini, G.; et al. A staging system for renal outcome and early markers of renal response to chemotherapy in AL amyloidosis. Blood 2014, 124, 2325-2332. [CrossRef]

10. Kastritis, E.; Gavriatopoulou, M.; Roussou, M.; Migkou, M.; Fotiou, D.; Ziogas, D.C.; Kanellias, N.; Eleutherakis-Papaiakovou, E.; Panagiotidis, I.; Giannouli, S.; et al. Renal outcomes in patients with AL amyloidosis: Prognostic factors, renal response and the impact of therapy. Am. J. Hematol. 2017, 92, 632-639. [CrossRef]

11. Wechalekar, A.D. Biomarkers in AL amyloidosis: Is the summit in sight? Blood 2018, 131, 1502-1503. [CrossRef] [PubMed]

12. Merlini, G.; Lousada, I.; Ando, Y.; Dispenzieri, A.; Gertz, M.A.; Grogan, M.; Maurer, M.S.; Sanchorawala, V.; Wechalekar, A.; Palladini, G.; et al. Rationale, application and clinical qualification for NT-proBNP as a surrogate end point in pivotal clinical trials in patients with AL amyloidosis. Leukemia 2016, 30, 1979-1986. [CrossRef] [PubMed]

13. Dispenzieri, A.; Gertz, M.A.; Kumar, S.K.; Lacy, M.Q.; Kyle, R.A.; Saenger, A.K.; Grogan, M.; Zeldenrust, S.R.; Hayman, S.R.; Buadi, F.; et al. High sensitivity cardiac troponin T in patients with immunoglobulin light chain amyloidosis. Heart 2014, 100, 383-388. [CrossRef] [PubMed]

14. Jaffe, A.S.; Ravkilde, J.; Roberts, R.; Naslund, U.; Apple, F.S.; Galvani, M.; Katus, H. It's time for a change to a troponin standard. Circulation 2000, 102, 1216-1220. [CrossRef] [PubMed]

15. Thygesen, K.; Alpert, J.S.; White, H.D.; Joint ESC/ACCF/AHA/WHF Task Force for the Redefinition of Myocardial Infarction. Universal definition of myocardial infarction. J. Am. Coll. Cardiol. 2007, 50, 2173-2195. [CrossRef] [PubMed]

16. Morrow, D.A.; Cannon, C.P.; Rifai, N.; Frey, M.J.; Vicari, R.; Lakkis, N.; Robertson, D.H.; Hille, D.A.; DeLucca, P.T.; DiBattiste, P.M.; et al. Ability of minor elevations of troponins I and T to predict benefit from an early invasive strategy in patients with unstable angina and non-ST elevation myocardial infarction: Results from a randomized trial. JAMA 2001, 286, 2405-2412. [CrossRef]

17. Merlini, G. AL amyloidosis: From molecular mechanisms to targeted therapies. Hematol. Am. Soc. Hematol. Educ. Program 2017, 2017, 1-12. [CrossRef]

18. Dittrich, T.; Bochtler, T.; Kimmich, C.; Becker, N.; Jauch, A.; Goldschmidt, H.; Ho, A.D.; Hegenbart, U.; Schonland, S.O. AL amyloidosis patients with low amyloidogenic free light chain levels at first diagnosis have an excellent prognosis. Blood 2017, 130, 632-642. [CrossRef]

19. Milani, P.; Basset, M.; Russo, F.; Foli, A.; Lavatelli, F.; Nuvolone, M.; Ferraro, G.; Palladini, G.; Merlini, G. Patients with AL amyloidosis and low free light-chain burden have distinct clinical features and outcome. Amyloid 2017, 24 (Suppl. S1), 64-65. [CrossRef]

20. Abraham, R.S.; Katzmann, J.A.; Clark, R.J.; Bradwell, A.R.; Kyle, R.A.; Gertz, M.A. Quantitative analysis of serum free light chains. A new marker for the diagnostic evaluation of primary systemic amyloidosis. Am. J. Clin. Pathol. 2003, 119, 274-278. [CrossRef]

21. Kumar, S.; Dispenzieri, A.; Katzmann, J.A.; Larson, D.R.; Colby, C.L.; Lacy, M.Q.; Hayman, S.R.; Buadi, F.K.; Leung, N.; Zeldenrust, S.R.; et al. Serum immunoglobulin free light-chain measurement in primary amyloidosis: Prognostic value and correlations with clinical features. Blood 2010, 116, 5126-5129. [CrossRef] [PubMed]

22. Sachchithanantham, S.; Berlanga, O.; Alvi, A.; Mahmood, S.A.; Lachmann, H.J.; Gillmore, J.D.; Hawkins, P.N.; Harding, S.; Wechalekar, A.D. Immunoparesis defined by heavy+light chain suppression is a novel marker of long-term outcomes in cardiac AL amyloidosis. Br. J. Haematol. 2017, 179, 575-585. [CrossRef] [PubMed] 
23. Potter, J.M.; Simpson, A.J.; Kerrigan, J.; Southcott, E.; Salib, M.M.; Koerbin, G.; Hickman, P.E. The relationship of plasma creatinine (as eGFR) and high-sensitivity cardiac troponin and NT-proBNP concentrations in a hospital and community outpatient population. Clin. Biochem. 2017, 50, 813-815. [CrossRef]

24. Kristensen, S.L.; Jhund, P.S.; Mogensen, U.M.; Rorth, R.; Abraham, W.T.; Desai, A.; Dickstein, K.; Rouleau, J.L.; Zile, M.R.; Swedberg, K.; et al. Investigators, prognostic value of N-Terminal Pro-B-Type natriuretic peptide levels in heart failure patients with and without atrial fibrillation. Circ. Heart Fail. 2017, 10, e004409. [CrossRef]

25. Dittrich, T.; Benner, A.; Kimmich, C.; Siepen, F.A.D.; Veelken, K.; Kristen, A.V.; Bochtler, T.; Katus, H.A.; Muller-Tidow, C.; Hegenbart, U.; et al. Performance analysis of AL amyloidosis cardiac biomarker staging systems with special focus on renal failure and atrial arrhythmia. Haematologica 2019, 104, 1451-1459. [CrossRef]

26. Kastritis, E.; Dimopoulos, M.A. Recent advances in the management of AL Amyloidosis. Br. J. Haematol. 2016, 172, 170-186. [CrossRef]

27. Drosou, M.E.; Vaughan, L.E.; Muchtar, E.; Buadi, F.K.; Dingli, D.; Dispenzieri, A.; Fonder, A.L.; Gertz, M.A.; Go, R.S.; Gonsalves, W.I.; et al. Comparison of the current renal staging, progression and response criteria to predict renal survival in AL amyloidosis using a Mayo cohort. Am. J. Hematol. 2021, 96, 446-454. [CrossRef]

28. Palladini, G.; Barassi, A.; Klersy, C.; Pacciolla, R.; Milani, P.; Sarais, G.; Perlini, S.; Albertini, R.; Russo, P.; Foli, A.; et al. The combination of high-sensitivity cardiac troponin $\mathrm{T}$ (hs-cTnT) at presentation and changes in N-terminal natriuretic peptide type $\mathrm{B}$ (NT-proBNP) after chemotherapy best predicts survival in AL amyloidosis. Blood 2010, 116, 3426-3430. [CrossRef]

29. Lilleness, B.; Ruberg, F.L.; Mussinelli, R.; Doros, G.; Sanchorawala, V. Development and validation of a survival staging system incorporating BNP in patients with light chain amyloidosis. Blood 2019, 133, 215-223. [CrossRef] [PubMed]

30. Kristen, A.V.; Giannitsis, E.; Lehrke, S.; Hegenbart, U.; Konstandin, M.; Lindenmaier, D.; Merkle, C.; Hardt, S.; Schnabel, P.A.; Rocken, C.; et al. Assessment of disease severity and outcome in patients with systemic light-chain amyloidosis by the high-sensitivity troponin T assay. Blood 2010, 116, 2455-2461. [CrossRef] [PubMed]

31. Dispenzieri, A.; Dingli, D.; Kumar, S.K.; Rajkumar, S.V.; Lacy, M.Q.; Hayman, S.; Buadi, F.; Zeldenrust, S.; Leung, N.; DetweilerShort, K.; et al. Discordance between serum cardiac biomarker and immunoglobulin-free light-chain response in patients with immunoglobulin light-chain amyloidosis treated with immune modulatory drugs. Am. J. Hematol. 2010, 85, 757-759. [CrossRef] [PubMed]

32. Buss, S.J.; Emami, M.; Mereles, D.; Korosoglou, G.; Kristen, A.V.; Voss, A.; Schellberg, D.; Zugck, C.; Galuschky, C.; Giannitsis, E.; et al. Longitudinal left ventricular function for prediction of survival in systemic light-chain amyloidosis: Incremental value compared with clinical and biochemical markers. J. Am. Coll. Cardiol. 2012, 60, 1067-1076. [CrossRef] [PubMed]

33. Pun, S.C.; Landau, H.J.; Riedel, E.R.; Jordan, J.; Yu, A.F.; Hassoun, H.; Chen, C.L.; Steingart, R.M.; Liu, J.E. Prognostic and added value of two-dimensional global longitudinal strain for prediction of survival in patients with light chain amyloidosis undergoing autologous hematopoietic cell transplantation. J. Am. Soc. Echocardiogr. 2018, 31, 64-70. [CrossRef] [PubMed]

34. Sidana, S.; Tandon, N.; Brady, P.A.; Grogan, M.; Gertz, M.A.; Dispenzieri, A.; Lin, G.; Dingli, D.; Buadi, F.K.; Lacy, M.Q.; et al. Prognostic significance of holter monitor findings in patients with light chain amyloidosis. Mayo Clin. Proc. 2019, 94, 455-464. [CrossRef]

35. Kumar, S.; Dispenzieri, A.; Lacy, M.Q.; Hayman, S.R.; Leung, N.; Zeldenrust, S.R.; Buadi, F.K.; Kyle, R.A.; Rajkumar, S.V.; Gertz, M.A. Serum uric acid: Novel prognostic factor in primary systemic amyloidosis. Mayo Clin. Proc. 2008, 83, 297-303. [CrossRef] [PubMed]

36. Palladini, G.; Milani, P.; Basset, M.; Russo, F.; Lavatelli, F.; Nuvolone, M.; Ferraro, G.; Bozzola, M.; Foli, A.; Merlini, G. Urinary albumin to creatinine ratio in diagnosis and risk stratification of renal AL amyloidosis. Amyloid 2017, 24 (Suppl. S1), 68-69. [CrossRef]

37. Visram, A.; Al Saleh, A.S.; Parmar, H.; McDonald, J.S.; Lieske, J.C.; Vaxman, I.; Muchtar, E.; Hobbs, M.; Fonder, A.; Hwa, Y.L.; et al. Correlation between urine ACR and 24-h proteinuria in a real-world cohort of systemic AL amyloidosis patients. Blood Cancer J. 2020, 10, 124. [CrossRef]

38. Kimmich, C.R.; Terzer, T.; Benner, A.; Dittrich, T.; Veelken, K.; Carpinteiro, A.; Hansen, T.; Goldschmidt, H.; Seckinger, A.; Hose, D.; et al. Daratumumab for systemic AL amyloidosis: Prognostic factors and adverse outcome with nephrotic-range albuminuria. Blood 2020, 135, 1517-1530. [CrossRef]

39. Kocica, M.J.; Corno, A.F.; Carreras-Costa, F.; Ballester-Rodes, M.; Moghbel, M.C.; Cueva, C.N.; Lackovic, V.; Kanjuh, V.I.; Torrent-Guasp, F. The helical ventricular myocardial band: Global, three-dimensional, functional architecture of the ventricular myocardium. Eur. J. Cardiothorac. Surg. 2006, 29 (Suppl. S1), S21-S40. [CrossRef]

40. Vogelsberg, H.; Mahrholdt, H.; Deluigi, C.C.; Yilmaz, A.; Kispert, E.M.; Greulich, S.; Klingel, K.; Kandolf, R.; Sechtem, U. Cardiovascular magnetic resonance in clinically suspected cardiac amyloidosis: Noninvasive imaging compared to endomyocardial biopsy. J. Am. Coll. Cardiol. 2008, 51, 1022-1030. [CrossRef]

41. Koyama, J.; Falk, R.H. Prognostic significance of strain Doppler imaging in light-chain amyloidosis. JACC Cardiovasc. Imaging 2010, 3, 333-342. [CrossRef]

42. Krishnasamy, R.; Isbel, N.M.; Hawley, C.M.; Pascoe, E.M.; Burrage, M.; Leano, R.; Haluska, B.A.; Marwick, T.H.; Stanton, T. Left ventricular global longitudinal strain (GLS) is a superior predictor of all-cause and cardiovascular mortality when compared to ejection fraction in advanced chronic kidney disease. PLoS ONE 2015, 10, e0127044. [CrossRef] 
43. Sengelov, M.; Jorgensen, P.G.; Jensen, J.S.; Bruun, N.E.; Olsen, F.J.; Fritz-Hansen, T.; Nochioka, K.; Biering-Sorensen, T. Global longitudinal strain is a superior predictor of all-cause mortality in heart failure with reduced ejection fraction. JACC Cardiovasc. Imaging 2015, 8, 1351-1359. [CrossRef] [PubMed]

44. Migrino, R.Q.; Christenson, R.; Szabo, A.; Bright, M.; Truran, S.; Hari, P. Prognostic implication of late gadolinium enhancement on cardiac MRI in light chain (AL) amyloidosis on long term follow up. BMC Med. Phys. 2009, 9, 5. [CrossRef] [PubMed]

45. Arenja, N.; Andre, F.; Riffel, J.H.; Siepen, F.A.D.; Hegenbart, U.; Schonland, S.; Kristen, A.V.; Katus, H.A.; Buss, S.J. Prognostic value of novel imaging parameters derived from standard cardiovascular magnetic resonance in high risk patients with systemic light chain amyloidosis. J. Cardiovasc. Magn. Reson. 2019, 21, 53. [CrossRef] [PubMed]

46. Sado, D.M.; White, S.K.; Piechnik, S.K.; Banypersad, S.M.; Treibel, T.; Captur, G.; Fontana, M.; Maestrini, V.; Flett, A.S.; Robson, M.D.; et al. Identification and assessment of Anderson-Fabry disease by cardiovascular magnetic resonance noncontrast myocardial T1 mapping. Circ. Cardiovasc. Imaging 2013, 6, 392-398. [CrossRef]

47. Lin, L.; Li, X.; Feng, J.; Shen, K.N.; Tian, Z.; Sun, J.; Mao, Y.Y.; Cao, J.; Jin, Z.Y.; Li, J.; et al. The prognostic value of T1 mapping and late gadolinium enhancement cardiovascular magnetic resonance imaging in patients with light chain amyloidosis. J. Cardiovasc. Magn. Reson. 2018, 20, 2. [CrossRef]

48. Kourelis, T.V.; Kumar, S.K.; Gertz, M.A.; Lacy, M.Q.; Buadi, F.K.; Hayman, S.R.; Zeldenrust, S.; Leung, N.; Kyle, R.A.; Russell, S.; et al. Coexistent multiple myeloma or increased bone marrow plasma cells define equally high-risk populations in patients with immunoglobulin light chain amyloidosis. J. Clin. Oncol. 2013, 31, 4319-4324. [CrossRef]

49. Tovar, N.; Rodriguez-Lobato, L.G.; Cibeira, M.T.; Magnano, L.; Isola, I.; Rosinol, L.; Blade, J.; Fernandez de Larrea, C. Bone marrow plasma cell infiltration in light chain amyloidosis: Impact on organ involvement and outcome. Amyloid 2018, 25, 79-85. [CrossRef]

50. Muchtar, E.; Dispenzieri, A.; Kumar, S.K.; Buadi, F.K.; Lacy, M.Q.; Zeldenrust, S.; Hayman, S.R.; Leung, N.; Kourelis, T.V.; Gonsalves, W.; et al. Immunoparesis in newly diagnosed AL amyloidosis is a marker for response and survival. Amyloid 2017, 24 (Suppl. S1), 40-41. [CrossRef]

51. Puig, N.; Paiva, B.; Lasa, M.; Burgos, L.; Perez, J.J.; Merino, J.; Moreno, C.; Vidriales, M.B.; Toboso, D.G.; Cedena, M.T.; et al. Flow cytometry for fast screening and automated risk assessment in systemic light-chain amyloidosis. Leukemia 2019, 33, $1256-1267$. [CrossRef] [PubMed]

52. Paiva, B.; Vidriales, M.B.; Perez, J.J.; Lopez-Berges, M.C.; Garcia-Sanz, R.; Ocio, E.M.; de Las Heras, N.; Cuello, R.; Garcia de Coca, A.; Pardal, E.; et al. The clinical utility and prognostic value of multiparameter flow cytometry immunophenotyping in light-chain amyloidosis. Blood 2011, 117, 3613-3616. [CrossRef]

53. Muchtar, E.; Dispenzieri, A.; Leung, N.; Lacy, M.Q.; Buadi, F.K.; Dingli, D.; Hayman, S.R.; Kapoor, P.; Hwa, Y.L.; Fonder, A.; et al. Optimizing deep response assessment for AL amyloidosis using involved free light chain level at end of therapy: Failure of the serum free light chain ratio. Leukemia 2019, 33, 527-531. [CrossRef] [PubMed]

54. Pardanani, A.; Witzig, T.E.; Schroeder, G.; McElroy, E.A.; Fonseca, R.; Dispenzieri, A.; Lacy, M.Q.; Lust, J.A.; Kyle, R.A.; Greipp, P.R.; et al. Circulating peripheral blood plasma cells as a prognostic indicator in patients with primary systemic amyloidosis. Blood 2003, 101, 827-830. [CrossRef] [PubMed]

55. Dispenzieri, A.; Lacy, M.Q.; Katzmann, J.A.; Rajkumar, S.V.; Abraham, R.S.; Hayman, S.R.; Kumar, S.K.; Clark, R.; Kyle, R.A.; Litzow, M.R.; et al. Absolute values of immunoglobulin free light chains are prognostic in patients with primary systemic amyloidosis undergoing peripheral blood stem cell transplantation. Blood 2006, 107, 3378-3383. [CrossRef]

56. Milani, P.; Basset, M.; Russo, F.; Foli, A.; Merlini, G.; Palladini, G. Patients with light-chain amyloidosis and low free light-chain burden have distinct clinical features and outcome. Blood 2017, 130, 625-631. [CrossRef]

57. Kastritis, E.; Palladini, G.; Minnema, M.C.; Wechalekar, A.D.; Jaccard, A.; Lee, H.C.; Sanchorawala, V.; Gibbs, S.; Mollee, P.; Venner, C.P.; et al. Daratumumab-based treatment for immunoglobulin light-chain amyloidosis. N. Engl. J. Med. 2021, 385, 46-58. [CrossRef] [PubMed]

58. Muchtar, E.; Jevremovic, D.; Dispenzieri, A.; Dingli, D.; Buadi, F.K.; Lacy, M.Q.; Gonsalves, W.; Hayman, S.R.; Kapoor, P.; Leung, N.; et al. The prognostic value of multiparametric flow cytometry in AL amyloidosis at diagnosis and at the end of first-line treatment. Blood 2017, 129, 82-87. [CrossRef]

59. Hammons, L.; Brazauskas, R.; Pasquini, M.; Hamadani, M.; Hari, P.; D’Souza, A. Presence of fluorescent in situ hybridization abnormalities is associated with plasma cell burden in light chain amyloidosis. Hematol. Oncol. Stem Cell Ther. 2018, 11, 105-111. [CrossRef]

60. Muchtar, E.; Dispenzieri, A.; Kumar, S.K.; Ketterling, R.P.; Dingli, D.; Lacy, M.Q.; Buadi, F.K.; Hayman, S.R.; Kapoor, P.; Leung, N.; et al. Interphase fluorescence in situ hybridization in untreated AL amyloidosis has an independent prognostic impact by abnormality type and treatment category. Leukemia 2017, 31, 1562-1569. [CrossRef]

61. Wong, S.W.; Hegenbart, U.; Palladini, G.; Shah, G.L.; Landau, H.J.; Warner, M.; Toskic, D.; Jaccard, A.; Hansen, T.; Blade, J.; et al. Outcome of patients with newly diagnosed systemic light-chain amyloidosis associated with deletion of 17p. Clin. Lymphoma Myeloma Leuk. 2018, 18, e493-e499. [CrossRef] [PubMed]

62. Bochtler, T.; Hegenbart, U.; Kunz, C.; Granzow, M.; Benner, A.; Seckinger, A.; Kimmich, C.; Goldschmidt, H.; Ho, A.D.; Hose, D.; et al. Translocation $\mathrm{t}(11 ; 14)$ is associated with adverse outcome in patients with newly diagnosed AL amyloidosis when treated with bortezomib-based regimens. J. Clin. Oncol. 2015, 33, 1371-1378. [CrossRef] 
63. Hayman, S.R.; Bailey, R.J.; Jalal, S.M.; Ahmann, G.J.; Dispenzieri, A.; Gertz, M.A.; Greipp, P.R.; Kyle, R.A.; Lacy, M.Q.; Rajkumar, S.V.; et al. Translocations involving the immunoglobulin heavy-chain locus are possible early genetic events in patients with primary systemic amyloidosis. Blood 2001, 98, 2266-2268. [CrossRef]

64. Bochtler, T.; Hegenbart, U.; Kunz, C.; Benner, A.; Seckinger, A.; Dietrich, S.; Granzow, M.; Neben, K.; Goldschmidt, H.; Ho, A.D.; et al. Gain of chromosome 1q21 is an independent adverse prognostic factor in light chain amyloidosis patients treated with melphalan/dexamethasone. Amyloid 2014, 21, 9-17. [CrossRef]

65. Bochtler, T.; Hegenbart, U.; Heiss, C.; Benner, A.; Cremer, F.; Volkmann, M.; Ludwig, J.; Perz, J.B.; Ho, A.D.; Goldschmidt, H.; et al. Evaluation of the serum-free light chain test in untreated patients with AL amyloidosis. Haematologica 2008, 93, 459-462. [CrossRef] [PubMed]

66. Lock, R.J.; Saleem, R.; Roberts, E.G.; Wallage, M.J.; Pesce, T.J.; Rowbottom, A.; Cooper, S.J.; McEvoy, E.D.; Taylor, J.L.; Basu, S. A multicentre study comparing two methods for serum free light chain analysis. Ann. Clin. Biochem. 2013, 50 Pt 3, $255-261$. [CrossRef] [PubMed]

67. Katzmann, J.A.; Clark, R.J.; Abraham, R.S.; Bryant, S.; Lymp, J.F.; Bradwell, A.R.; Kyle, R.A. Serum reference intervals and diagnostic ranges for free kappa and free lambda immunoglobulin light chains: Relative sensitivity for detection of monoclonal light chains. Clin. Chem. 2002, 48, 1437-1444. [CrossRef]

68. Muchtar, E.; Gertz, M.A.; Kourelis, T.V.; Sidana, S.; Go, R.S.; Lacy, M.Q.; Buadi, F.K.; Dingli, D.; Hayman, S.R.; Kapoor, P.; et al. Bone marrow plasma cells $20 \%$ or greater discriminate presentation, response, and survival in AL amyloidosis. Leukemia 2020, 34, 1135-1143. [CrossRef]

69. Muchtar, E.; Gertz, M.A.; Kumar, S.K.; Lacy, M.Q.; Dingli, D.; Buadi, F.K.; Grogan, M.; Hayman, S.R.; Kapoor, P.; Leung, N.; et al. Improved outcomes for newly diagnosed AL amyloidosis between 2000 and 2014: Cracking the glass ceiling of early death. Blood 2017, 129, 2111-2119. [CrossRef] [PubMed]

70. Bochtler, T.; Hegenbart, U.; Heiss, C.; Benner, A.; Moos, M.; Seckinger, A.; Pschowski-Zuck, S.; Kirn, D.; Neben, K.; Bartram, C.R.; et al. Hyperdiploidy is less frequent in AL amyloidosis compared with monoclonal gammopathy of undetermined significance and inversely associated with translocation $\mathrm{t}(11 ; 14)$. Blood 2011, 117, 3809-3815. [CrossRef]

71. Bochtler, T.; Hegenbart, U.; Kunz, C.; Benner, A.; Kimmich, C.; Seckinger, A.; Hose, D.; Goldschmidt, H.; Granzow, M.; Dreger, P.; et al. Prognostic impact of cytogenetic aberrations in AL amyloidosis patients after high-dose melphalan: A long-term follow-up study. Blood 2016, 128, 594-602. [CrossRef] [PubMed]

72. Warsame, R.; Kumar, S.K.; Gertz, M.A.; Lacy, M.Q.; Buadi, F.K.; Hayman, S.R.; Leung, N.; Dingli, D.; Lust, J.A.; Ketterling, R.P.; et al. Abnormal FISH in patients with immunoglobulin light chain amyloidosis is a risk factor for cardiac involvement and for death. Blood Cancer J. 2015, 5, e310. [CrossRef] [PubMed]

73. Palladini, G.; Dispenzieri, A.; Gertz, M.A.; Kumar, S.; Wechalekar, A.; Hawkins, P.N.; Schonland, S.; Hegenbart, U.; Comenzo, R.; Kastritis, E.; et al. New criteria for response to treatment in immunoglobulin light chain amyloidosis based on free light chain measurement and cardiac biomarkers: Impact on survival outcomes. J. Clin. Oncol. 2012, 30, 4541-4549. [CrossRef] [PubMed]

74. Muchtar, E.; Dispenzieri, A.; Leung, N.; Lacy, M.Q.; Buadi, F.K.; Dingli, D.; Grogan, M.; Hayman, S.R.; Kapoor, P.; Hwa, Y.L.; et al. Depth of organ response in AL amyloidosis is associated with improved survival: Grading the organ response criteria. Leukemia 2018, 32, 2240-2249. [CrossRef] [PubMed]

75. Manwani, R.; Foard, D.; Mahmood, S.; Sachchithanantham, S.; Lane, T.; Quarta, C.; Youngstein, T.; Rezk, T.; Lachmann, H.J.; Gillmore, J.D.; et al. Rapid hematologic responses improve outcomes in patients with very advanced (stage IIIb) cardiac immunoglobulin light chain amyloidosis. Haematologica 2018, 103, e165-e168. [CrossRef] [PubMed]

76. Sanchorawala, V.; Seldin, D.C.; Magnani, B.; Skinner, M.; Wright, D.G. Serum free light-chain responses after high-dose intravenous melphalan and autologous stem cell transplantation for AL (primary) amyloidosis. Bone Marrow Transpl. 2005, 36, 597-600. [CrossRef]

77. Nguyen, V.P.; Rosenberg, A.; Mendelson, L.M.; Comenzo, R.L.; Varga, C.; Sanchorawala, V. Outcomes of patients with AL amyloidosis and low serum free light chain levels at diagnosis. Amyloid 2018, 25, 156-159. [CrossRef] [PubMed]

78. Qiu, Y.; Zhang, C.L.; Shen, K.N.; Su, W.; Feng, J.; Zhang, L.; Cao, X.X.; Li, J. Clinical presentation and prognosis of light-chain amyloidosis patients with unmeasurable free light-chain levels. Ann. Hematol. 2018, 97, 2465-2470. [CrossRef]

79. Manwani, R.; Cohen, O.; Sharpley, F.; Mahmood, S.; Sachchithanantham, S.; Foard, D.; Lachmann, H.J.; Quarta, C.; Fontana, M.; Gillmore, J.D.; et al. A prospective observational study of 915 patients with systemic AL amyloidosis treated with upfront bortezomib. Blood 2019, 134, 2271-2280. [CrossRef]

80. Muchtar, E.; Dispenzieri, A.; Jevremovic, D.; Dingli, D.; Buadi, F.K.; Lacy, M.Q.; Gonsalves, W.; Warsame, R.; Kourelis, T.V.; Hayman, S.R.; et al. Survival impact of achieving minimal residual negativity by multi-parametric flow cytometry in AL amyloidosis. Amyloid 2020, 27, 13-16. [CrossRef]

81. Preusch, M.R.; Baeuerle, M.; Albrecht, C.; Blessing, E.; Bischof, M.; Katus, H.A.; Bea, F. GDF-15 protects from macrophage accumulation in a mousemodel of advanced atherosclerosis. Eur. J. Med. Res. 2013, 18, 19. [CrossRef]

82. Dispenzieri, A.; Gertz, M.A.; Saenger, A.; Kumar, S.K.; Lacy, M.Q.; Buadi, F.K.; Dingli, D.; Leung, N.; Zeldenrust, S.; Hayman, S.R.; et al. Soluble suppression of tumorigenicity 2 (sST2), but not galactin-3, adds to prognostication in patients with systemic AL amyloidosis independent of NT-proBNP and troponin T. Am. J. Hematol. 2015, 90, 524-528. [CrossRef] 
83. Hayek, S.S.; Koh, K.H.; Grams, M.E.; Wei, C.; Ko, Y.A.; Li, J.; Samelko, B.; Lee, H.; Dande, R.R.; Lee, H.W.; et al. A tripartite complex of suPAR, APOL1 risk variants and $\alpha(\mathrm{v}) \beta(3)$ integrin on podocytes mediates chronic kidney disease. Nat. Med. 2017, 23, 945-953. [CrossRef]

84. Lupon, J.; de Antonio, M.; Galan, A.; Vila, J.; Zamora, E.; Urrutia, A.; Bayes-Genis, A. Combined use of the novel biomarkers high-sensitivity troponin T and ST2 for heart failure risk stratification vs conventional assessment. Mayo Clin. Proc. 2013, 88 , 234-243. [CrossRef]

85. Drechsler, C.; Delgado, G.; Wanner, C.; Blouin, K.; Pilz, S.; Tomaschitz, A.; Kleber, M.E.; Dressel, A.; Willmes, C.; Krane, V.; et al. Galectin-3, renal function, and clinical outcomes: Results from the LURIC and 4D studies. J. Am. Soc. Nephrol. 2015, 26, $2213-2221$. [CrossRef]

86. Waller, A.H.; Sanchez-Ross, M.; Kaluski, E.; Klapholz, M. Osteopontin in cardiovascular disease: A potential therapeutic target. Cardiol. Rev. 2010, 18, 125-131. [CrossRef] [PubMed]

87. Pudusseri, A.; Sanchorawala, V.; Sloan, J.M.; Bever, K.M.; Doros, G.; Kataria, S.; Sarosiek, S. Prevalence and prognostic value of D-dimer elevation in patients with AL amyloidosis. Am. J. Hematol. 2019, 94, 1098-1103. [CrossRef] [PubMed]

88. Sidana, S.; Muchtar, E.; Sidiqi, M.H.; Jevremovic, D.; Dispenzieri, A.; Gonsalves, W.; Buadi, F.; Lacy, M.Q.; Hayman, S.R.; Kourelis, T.; et al. Impact of minimal residual negativity using next generation flow cytometry on outcomes in light chain amyloidosis. Am. J. Hematol. 2020, 95, 497-502. [CrossRef]

89. Jaiswal, S.; Fontanillas, P.; Flannick, J.; Manning, A.; Grauman, P.V.; Mar, B.G.; Lindsley, R.C.; Mermel, C.H.; Burtt, N.; Chavez, A.; et al. Age-related clonal hematopoiesis associated with adverse outcomes. N. Engl. J. Med. 2014, 371, 2488-2498. [CrossRef]

90. Park, K.H.; Han, S.J.; Kim, H.S.; Jo, S.H.; Kim, S.A.; Park, W.J. Endothelial function and cardiovascular autonomic activity in neurally mediated syncope. Cardiology 2016, 134, 65-71. [CrossRef] [PubMed]

91. Kastritis, E.; Papassotiriou, I.; Terpos, E.; Roussou, M.; Gavriatopoulou, M.; Komitopoulou, A.; Skevaki, C.; EleutherakisPapaiakovou, E.; Pamboucas, C.; Psimenou, E.; et al. Clinical and prognostic significance of serum levels of von Willebrand factor and ADAMTS-13 antigens in AL amyloidosis. Blood 2016, 128, 405-409. [CrossRef]

92. Ai, L.; Mu, S.; Hu, Y. Prognostic role of RDW in hematological malignancies: A systematic review and meta-analysis. Cancer Cell Int. 2018, 18, 61. [CrossRef]

93. Yogo, T.; Okazuka, K.; Nashimoto, J.; Uto, Y.; Sato, K.; Miyazaki, K.; Ogura, M.; Yoshiki, Y.; Abe, Y.; Tsukada, N.; et al. Red blood cell distribution width is a simple and novel biomarker for survival in light-chain amyloidosis. Int. J. Hematol. 2019, 110, 431-437. [CrossRef]

94. Dhillon, O.S.; Narayan, H.K.; Khan, S.Q.; Kelly, D.; Quinn, P.A.; Squire, I.B.; Davies, J.E.; Ng, L.L. Pre-discharge risk stratification in unselected STEMI: Is there a role for ST2 or its natural ligand IL-33 when compared with contemporary risk markers? Int. J. Cardiol. 2013, 167, 2182-2188. [CrossRef]

95. Gruson, D.; Lepoutre, T.; Ahn, S.A.; Rousseau, M.F. Increased soluble ST2 is a stronger predictor of long-term cardiovascular death than natriuretic peptides in heart failure patients with reduced ejection fraction. Int. J. Cardiol. 2014, 172, e250-e252. [CrossRef]

96. Weinberg, E.O.; Shimpo, M.; De Keulenaer, G.W.; MacGillivray, C.; Tominaga, S.; Solomon, S.D.; Rouleau, J.L.; Lee, R.T. Expression and regulation of ST2, an interleukin-1 receptor family member, in cardiomyocytes and myocardial infarction. Circulation 2002, 106, 2961-2966. [CrossRef] [PubMed]

97. Sabatine, M.S.; Morrow, D.A.; Higgins, L.J.; MacGillivray, C.; Guo, W.; Bode, C.; Rifai, N.; Cannon, C.P.; Gerszten, R.E.; Lee, R.T. Complementary roles for biomarkers of biomechanical strain ST2 and N-terminal prohormone B-type natriuretic peptide in patients with ST-elevation myocardial infarction. Circulation 2008, 117, 1936-1944. [CrossRef]

98. Kim, D.; Lee, G.Y.; Choi, J.O.; Kim, K.; Kim, S.J.; Ju, E.S.; Jeon, E.S. Prognostic values of novel biomarkers in patients with AL amyloidosis. Sci. Rep. 2019, 9, 12200. [CrossRef] [PubMed]

99. Denhardt, D.T.; Guo, X. Osteopontin: A protein with diverse functions. FASEB J. 1993, 7, 1475-1482. [CrossRef] [PubMed]

100. Rosenberg, M.; Zugck, C.; Nelles, M.; Juenger, C.; Frank, D.; Remppis, A.; Giannitsis, E.; Katus, H.A.; Frey, N. Osteopontin, a new prognostic biomarker in patients with chronic heart failure. Circ. Heart Fail. 2008, 1, 43-49. [CrossRef]

101. Kristen, A.V.; Rosenberg, M.; Lindenmaier, D.; Merkle, C.; Steen, H.; Andre, F.; Schonland, S.O.; Schnabel, P.A.; Schuster, T.; Rocken, C.; et al. Osteopontin: A novel predictor of survival in patients with systemic light-chain amyloidosis. Amyloid 2014, 21, 202-210. [CrossRef] [PubMed]

102. Bernardi, L.; Passino, C.; Porta, C.; Anesi, E.; Palladini, G.; Merlini, G. Widespread cardiovascular autonomic dysfunction in primary amyloidosis: Does spontaneous hyperventilation have a compensatory role against postural hypotension? Heart 2002, 88, 615-621. [CrossRef] [PubMed]

103. Harris, R.A.; Nishiyama, S.K.; Wray, D.W.; Richardson, R.S. Ultrasound assessment of flow-mediated dilation. Hypertension 2010, 55, 1075-1085. [CrossRef] [PubMed]

104. Stamatelopoulos, K.; Georgiopoulos, G.; Athanasouli, F.; Nikolaou, P.E.; Lykka, M.; Roussou, M.; Gavriatopoulou, M.; Laina, A.; Trakada, G.; Charakida, M.; et al. Reactive vasodilation predicts mortality in primary systemic light-chain amyloidosis. Circ. Res. 2019, 125, 744-758. [CrossRef] [PubMed]

105. Kastritis, E.; Papassotiriou, I.; Merlini, G.; Milani, P.; Terpos, E.; Basset, M.; Akalestos, A.; Russo, F.; Psimenou, E.; Apostolakou, F.; et al. Growth differentiation factor-15 is a new biomarker for survival and renal outcomes in light chain amyloidosis. Blood 2018, 131, 1568-1575. [CrossRef] [PubMed] 
106. Wollert, K.C.; Kempf, T. Growth differentiation factor 15 in heart failure: An update. Curr. Heart Fail. Rep. $2012,9,337-345$. [CrossRef]

107. Huai, Q.; Mazar, A.P.; Kuo, A.; Parry, G.C.; Shaw, D.E.; Callahan, J.; Li, Y.; Yuan, C.; Bian, C.; Chen, L. Structure of human urokinase plasminogen activator in complex with its receptor. Science 2006, 311, 656-659. [CrossRef]

108. Thuno, M.; Macho, B.; Eugen-Olsen, J. suPAR: The molecular crystal ball. Dis. Markers 2009, 27, 157-172. [CrossRef]

109. Koller, L.; Stojkovic, S.; Richter, B.; Sulzgruber, P.; Potolidis, C.; Liebhart, F.; Mörtl, D.; Berger, R.; Goliasch, G.; Wojta, J.; et al. Soluble urokinase-type plasminogen activator receptor improves risk prediction in patients with chronic heart failure. JACC Heart Fail. 2017, 5, 268-277. [CrossRef]

110. Hayek, S.S.; Sever, S.; Ko, Y.A.; Trachtman, H.; Awad, M.; Wadhwani, S.; Altintas, M.M.; Wei, C.; Hotton, A.L.; French, A.L.; et al. Soluble urokinase receptor and chronic kidney disease. N. Engl. J. Med. 2015, 373, 1916-1925. [CrossRef]

111. Kastritis, E.; Papassotiriou, I.; Theodorakakou, F.; Margeli, A.; Barzteliotou, A.; Tsiligkeridou, E.; Andreatou, A.; Fotiou, D.; Migkou, M.; Kanellias, N. Soluble Urokinase-type Plasminogen Activator Receptor (suPAR) as a biomarker of renal outcomes in AL amyloidosis. In Blood; American Society of Hematology: Washington, DC, USA, 2020.

112. Li, T.; Huang, X.; Wang, Q.; Zhao, L.; Ren, G.; Chen, W.; Zheng, C.; Zhou, M.; Jiang, Q.; Yin, R.; et al. A risk stratification for systemic immunoglobulin light-chain amyloidosis with renal involvement. Br. J. Haematol. 2019, 187, 459-469. [CrossRef] [PubMed] 